\title{
Emerging Roles of microRNAs in Ischemic Stroke: As Possible Therapeutic Agents
}

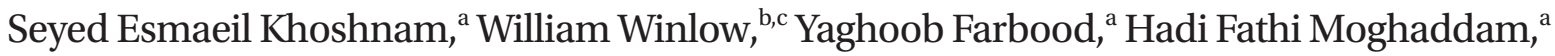 \\ Maryam Farzaneh ${ }^{\mathrm{d}}$ \\ aDepartment of Physiology, Faculty of Medicine, Physiology Research Center, Ahvaz Jundishapur University of Medical Sciences, Ahvaz, Iran \\ bDipartimento di Biologia, Università degli Studi di Napoli, Napoli, Italia \\ Institute of Ageing and Chronic Diseases, University of Liverpool, Liverpool, UK \\ ${ }^{d}$ Department of Stem Cells and Developmental Biology, Cell Science Research Center, Royan Institute for Stem Cell Biology and Technology, \\ ACECR, Tehran, Iran
}

\begin{abstract}
Stroke is one of the leading causes of death and physical disability worldwide. The consequences of stroke injuries are profound and persistent, causing in considerable burden to both the individual patient and society. Current treatments for ischemic stroke injuries have proved inadequate, partly owing to an incomplete understanding of the cellular and molecular changes that occur following ischemic stroke. MicroRNAs (miRNA) are endogenously expressed RNA molecules that function to inhibit mRNA translation and have key roles in the pathophysiological processes contributing to ischemic stroke injuries. Potential therapeutic areas to compensate these pathogenic processes include promoting angiogenesis, neurogenesis and neuroprotection. Several miRNAs, and their target genes, are recognized to be involved in these recoveries and repair mechanisms. The capacity of miRNAs to simultaneously regulate several target genes underlies their unique importance in ischemic stroke therapeutics. In this Review, we focus on the role of miRNAs as potential diagnostic and prognostic biomarkers, as well as promising therapeutic agents in cerebral ischemic stroke.
\end{abstract}

Keywords Ischemia; Stroke; MicroRNAs

\author{
Correspondence: Seyed Esmaeil \\ Khoshnam \\ Department of Physiology, Faculty of \\ Medicine, Physiology Research Center, \\ Ahvaz Jundishapur University of \\ Medical Sciences, Ahvaz, Iran \\ Tel: +98-917-1491729 \\ Fax: +98-6113738248 \\ E-mail: Esmaeil.khoshnam1392@gmail.com \\ Received: September 16, 2016 \\ Revised: February 8, 2017 \\ Accepted: February 27, 2017 \\ The authors have no financial conflicts \\ of interest.
}

\section{Introduction}

\section{Stroke}

Stroke is the major cause of adult physical disability and the second leading cause of death in the world. ${ }^{1,2}$ Stroke is one of the most important and devastating of all neurological disorders, accounting for 5.5 million deaths annually, with 44 million physical disabilities worldwide. ${ }^{3}$ The consequences of stroke injuries are profound and persistent, causing a high burden to both the individual patient and society because of their increasing incidence, the physical disability and mortality they cause, and their economic impact, mainly in low- and middle-income countries. ${ }^{4}$
Ischemic stroke is responsible for $80 \%$ of all strokes, while hemorrhagic stroke accounts for $15 \%$ and the other $5 \%$ are due to unknown etiology. ${ }^{5}$ In the present review we will discuss the pathogenic mechanisms related to ischemic stroke such as excitotoxicity, oxidative stress, inflammation and apoptosis, and how microRNAs may play a role in these pathogenic process. We will also investigate miRNAs that involved in the post-stroke recovery and repair pathways.

\section{Pathophysiology of cerebral ischemia}

Cerebral ischemia, which leads to brain dysfunction, results from cerebral artery occlusion that decreases cerebral blood flow, and its symptoms last for 24 hours or more. ${ }^{6}$ During isch- 
emic stroke, neurons are deprived of oxygen and energy, so that their normal metabolic substrates stop functioning in seconds and display signs of structural injury after only 2 minutes. ${ }^{7}$ Immediately after ischemia, cellular energy-dependent processes fail and neurons are unable to sustain their normal transmembrane ionic gradient, resulting in an imbalance between ions and water thus leading to apoptosis and necrotic cell death. ${ }^{8,9}$

During ischemia the brain tissues are not affected equally owing to differential lessening of blood supply to the different zones. Hence, ischemic injury involves the ischemic core and the penumbra region. ${ }^{10}$ Severe ischemia occurs in the ischemic core, where neuronal damage is irreversible due to necrotic cell death while the surrounding penumbra constitutes cells that are metabolically active and potentially salvageable. Therefore, the penumbral zone has the potential for recovery and is the target for therapeutic agents. ${ }^{11,12}$ Nevertheless, cerebral ischemia triggers several pathogenic processes (excitotoxicity, oxidative stress, inflammation and apoptosis) in the penumbra zone that leads to neuronal cell death (Figure 1). These processes are considered to be the central mechanisms underlying neuron death in ischemic stroke. ${ }^{13-15}$

\section{MicroRNAs}

miRNAs are small, non-protein-coding RNAs, which include 20-24 nucleotides that are highly conserved through evolution. They are post-transcriptional regulators that targeting the 3 '-untranslated regions (3'-UTRs) of target mRNAs, which lead

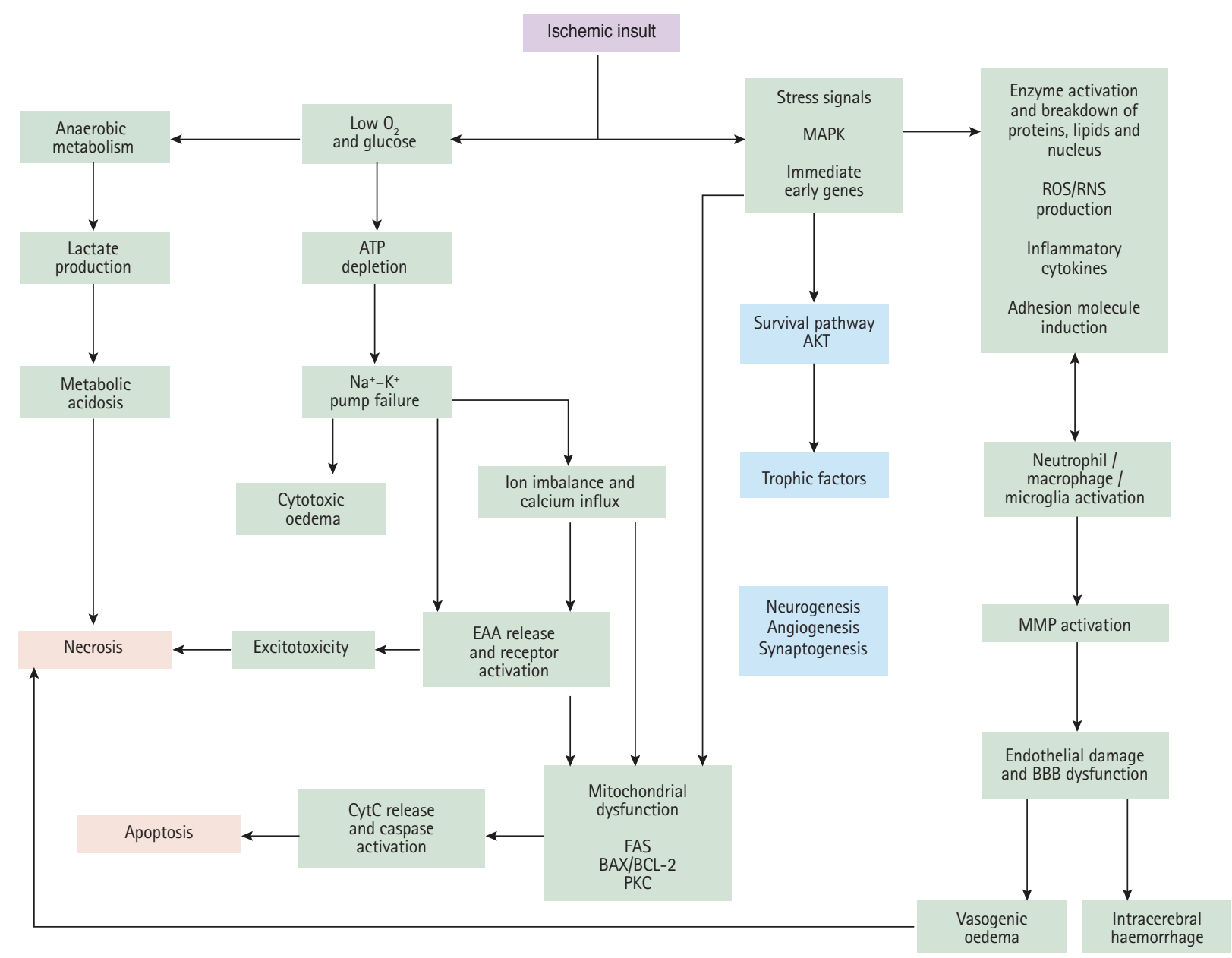

Figure 1. Critical events in the ischemic cascade. Following ischaemia, the deprivation of oxygen and glucose to the brain lead to loss of ATP (energy loss) and ion pump failure. The loss of ion concentration gradients causes cytotoxic oedema and releasing of excitatory amino acids (EAAs). Following reduced glucose availability cell aerobic metabolism switches to anaerobic, resulting in metabolic acidosis. All of these events lead to cell death, or necrosis. Ischaemia also causes the upregulation and activation of many immediate early genes and stress signals, which lead to inflammatory responses, cell apoptosis and, subsequently, activation of matrix metalloproteinases (MMPs) as a damaging protease which can lead to the brain oedema and haemorrhage. Following ischaemia, AKT kinase activation and upregulation of trophic factors set the stage for recovery and repair mechanisms which including neurogenesis, synaptogenesis and angiogenesis. AKT, protein kinase B; MAPK, mitogen-activated protein kinase; ROS/RNS, reactive oxygen species/reactive nitrogen species; ATP, adenosine triphosphate; EAA, excitatory amino acids; CytC, cytochrome c; FAS, the cell-surface Fas receptor; PKC, protein kinase $\mathrm{C}$; BBB, blood brain barrier. 
to the inhibition of translation or degradation of the respective mRNA. ${ }^{16}$ miRNAs have been implicated in the regulation of a variety of cellular processes and diseases such as neuronal development, differentiation, synaptic plasticity, proliferation, metabolism, apoptosis, neurodegenerative diseases and tumorigenesis. ${ }^{17-22}$ miRNAs are initially transcribed from genomic DNA, and RNA polymerase II is responsible for transcription of primary miRNA (pri-miRNA). ${ }^{23}$ Pri-miRNAs can be thousands of base pairs in length and consist of at least one hairpin loop, which is recognized and cleaved by the endonuclease Drosha, and which generates a precursor miRNA (pre-miRNA), with the help of DGCR8, a double stranded RNA-binding protein. ${ }^{24,25}$ The pre-miRNA is transported from the nucleus into the cytoplasm through the function of exportin-5. In the cytoplasm, the premiRNA undergoes cleavage by endoribonucleic Dicer to form a duplex of the mature miRNA strand, which is generally biologically active..$^{26-28}$

It is known that biological functions of miRNAs are extremely dependent on the cellular context and the precise link between miRNAs and stroke consequences should be discussed only within a specific cellular context. The studies showed that miRNAs have participated as key mediators in the molecular processes underlying cerebral ischemia and related diseases. ${ }^{29-32}$ Therefore, in the present study, we review all available relevant articles regarding miRNAs and ischemic stroke in order to explain the complex link between miRNA and ischemic stroke. The information about the stroke-miRNA system may be used for therapeutic and diagnostic methods in stroke treatment.

\section{MicroRNAs intervention in ischemic stroke progression}

In the past few decades, the clinical methods such as computed tomography scans and magnetic resonance imaging have facilitated diagnosis and prognosis of stroke. However, the diagnostic and prognostic powers are limited in availability and higher cost. ${ }^{33,34}$ Additional diagnostic tools including interleukin-6 (IL-6), matrix metallopeptidase 9 (MMP-9) and C-reactive protein (CRP), which their specificity and ability to distinguish between acute stroke and its related risk factors is unclear. ${ }^{35}$ Given the limited recommended therapeutic window for thrombolysis, new biomarkers are necessary for advancing diagnosis of stroke. Therefore, recent studies have suggested promising mRNA based biomarkers, which they could distinguish transient ischemic attack from control samples. ${ }^{36}$ Hence, several studies have reported the uses of miRNAs as circulating biomarkers for diagnosis or prognosis of stroke (Table 1).

Several pathogenic processes are involved in ischemic stroke progression which include excitotoxicity, oxidative stress, inflammation and apoptosis. ${ }^{37}$ The miRNAs discussed below regulate genes in these pathogenic processes by downregulating the gene expression (Figure 2, Table 2).

\section{Post-ischemic excitotoxicity}

Ischemic stroke damages brain tissue primarily through excitotoxicity, a term used to describe cell death induced by synaptic high levels of glutamate, which is a major excitatory neurotransmitter in the central nervous system (CNS). ${ }^{38}$ Several types of glutamate receptors have been identified in the CNS, and the three main types of these receptors are: $\alpha$-Amino-3-hydroxy-5-methyl-isoxazole-4-propionate (AMPA) receptors, N-Methyl-D-aspartate (NMDA) receptors and metabotropic glutamate receptors (mGluR). ${ }^{39-41}$ Excess glutamate over-activates NMDA and AMPA receptors on postsynaptic cells which facilitate influx of calcium ions into neurons..$^{37,42}$

Under basal synaptic transmission, activation of the synaptic NMDA receptors (predominantly NR2A-containing) stimulates the signaling components of the neuronal survival signaling complex (NSC) that promoting neuronal survival. ${ }^{43,44}$ However, under pathological conditions such as stroke, elevating of the extracellular glutamate concentration causing excitotoxic activation of extrasynaptic NMDA receptors (predominantly NR2B-containing). The NR2B activation increased $\mathrm{Ca}^{2}{ }^{+}$influx and promotes active death-associated protein kinase (aDAPK) to bind with NR2B. ${ }^{43-45}$ aDAPK recruitment promotes activating the neuronal death-signaling complex (NDC), that in turn suppress synaptic NSC activity, ${ }^{43}$ and mediate neuronal death. It is demonstrated that inhibition of aDAPK binding to the NR2B

Table 1. Overview of circulating miRNAs and their relationship with stroke

\begin{tabular}{lcc}
\hline miRNAs type & $\begin{array}{c}\text { Expression of miRNA } \\
\text { following stroke }\end{array}$ & Ref. \\
\hline miR-363, miR-487b & + & 249 \\
miR-210 & - & 218 \\
miR-124 & + & 250,251 \\
miR-122, miR-148a, let-7i, miR-19a, & - & 249 \\
miR-320d, miR-4429 & & \\
miR-30a, miR-126 & - & 252 \\
miR-125b-2, miR-27a, miR-422a, & + & 253 \\
miR-488, miR-627 & & \\
miR-290 & + & 29 \\
hsa-miR-106b-5P, hsa-miR-4306 & + & 254 \\
hsa-miR-320e, hsa-miR-320d & - & 254 \\
miR-124, miR-9, miR-219 & - & 136 \\
miR-10a, miR-182, miR-200b, miR-298 & + & 32
\end{tabular}

Ref., reference; +, increase; -, decrease. 


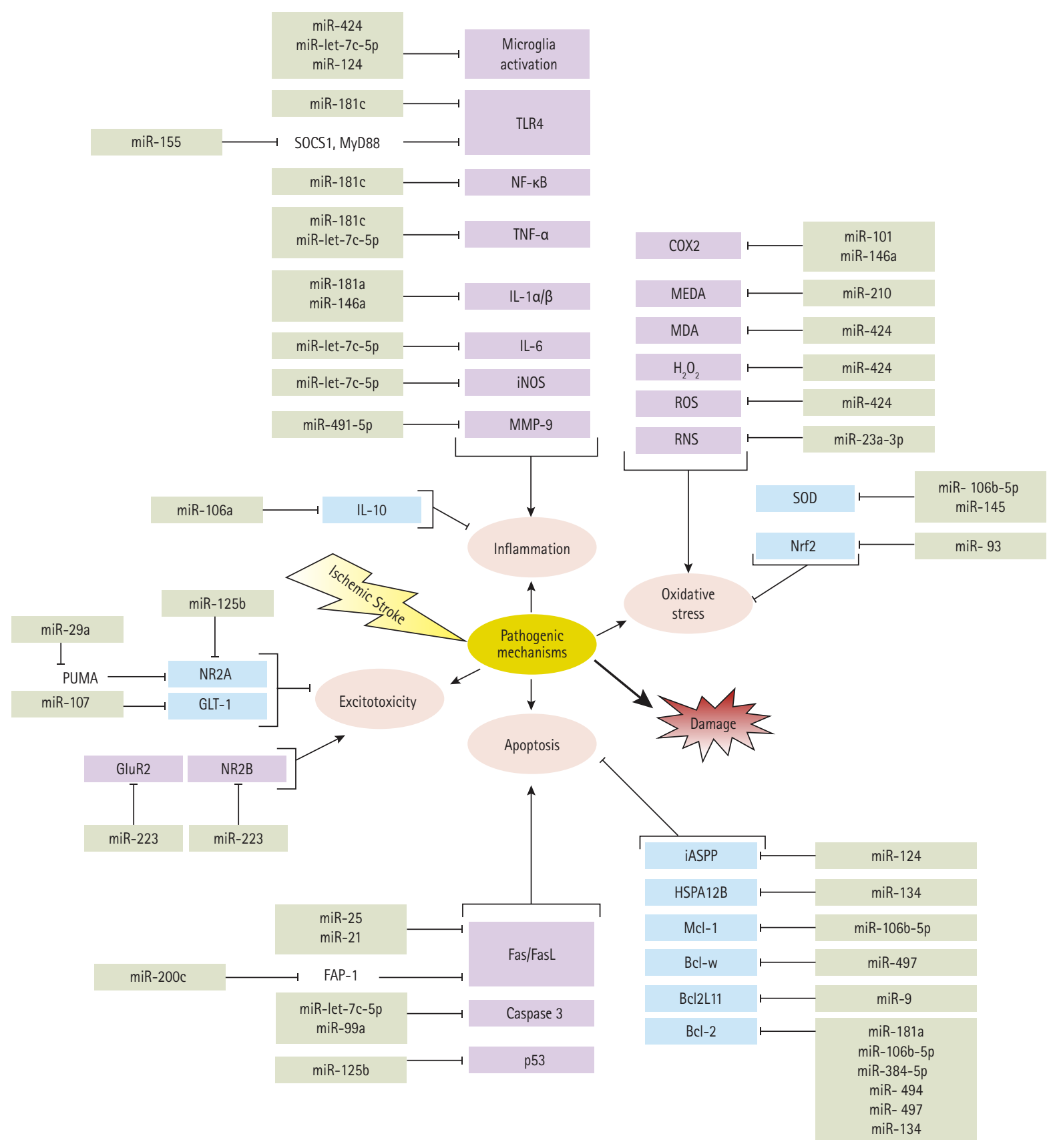

Figure 2. MicroRNAs involved in detrimental (purple boxes) and protective pathways (blue boxes) are activated by ischemic stroke. Cerebral ischemia, while activating detrimental pathways, also triggers some organized responses that counteract tissue injury. Post-ischemic oxidative stress triggers an oxidant and antioxidant responses via different factors which are inhibited by microRNAs. Oxidative agents that are inhibited by microRNAs, including reactive oxygen/nitrogen species (ROS/RNS), cyclooxygenase 2 (COX2), hydrogen peroxide $\left(\mathrm{H}_{2} \mathrm{O}_{2}\right)$, malondialdehyde (MDA) and methane dicarboxylic aldehyde (MEDA). The antioxidant response which is inhibited by microRNAs containing transcription factor Nrf2 and superoxide dismutase (SOD). Following ischemia, inflammation is increased by production of matrix metalloproteinases (MMP-9) to infiltrate the BBB, and activation of pro-inflammatory genes such as interleukin-1 (IL-1 $\alpha$

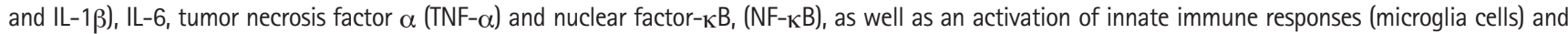
toll-like receptors (TLR4). Inflammation is mitigated by production of anti-inflammatory cytokines like such as IL-10. microRNAs could affect post-ischemic inflammatory and anti-inflammatory factors. Excitotoxicity associated with glutamate receptor activation can be counterbalance via glutamate transporter (GLT1) and NMDA (containing subunit NR2A), while glutamate receptors GluR2 and NMDA (containing subunit NR2B) exacerbate excitotoxic injuries. microRNAs inhibit those factors that contribute in the excitotoxicity. The detrimental effects of post-ischemic apoptosis are antagonized by activation and expression of antiapoptotic factors such as; Bcl-2, Bcl2L11, Bcl-w, Mcl-1 and the heat shock proteins family (HSPA12B). Hence, deleterious effects of apoptosis are induced by expression of caspase 3, activation of cell surface death receptors (Fas) and its ligand (FasL), and activation of p53, inhibitory member of the apoptosis-stimulating proteins of the p53 family (iASPP). There are some microRNAs which modulate the detrimental effects of post-ischemic apoptosis. SOCS1, suppressor of cytokine signaling 1; MyD88, myeloid differentiation primary response gene 88; iNOS, inducible nitric oxide synthase; Nrf2, nuclear factor erythroid-2 related factor 2; PUMA, p53 upregulated modulator of apoptosis; GLT-1, glutamate transporter-1; GluR2, glutamate receptor-2; FAP-1, Fas associated protein-tyrosine phosphatase 1. 
reduces activation of NDC and prevent the excitotoxic neuronal injury induced by ischemic stroke. ${ }^{45,46}$ So, the NR2B subunit is a major hub for NDC formation. ${ }^{45,47,48}$

Also, binding of glutamate to mGluR caused release of the intracellular calcium store. ${ }^{37,39}$ These events result in accumulation of intracellular calcium which changes the osmolarity of the cell and activation some of endogenous enzymes such as proteases, lipases and endonucleases. These enzymes degrade important cellular macromolecules such as structural proteins, membrane lipids and DNA. 37,39,49

\section{MicroRNAs and ischemic excitotoxicity}

Following ischemic stroke, overexpression of miR-107 leads to suppression of glutamate transporter-1 (GLT-1) expression and elevated glutamate accumulation, which determine the degree of excitotoxicity. ${ }^{50}$ Post-ischemic downregulation of GLT-1 is closely associated with accumulation of glutamate, suggesting that glutamate accumulation and neuronal excitotoxicity can be controlled via GLT-1 expression. ${ }^{51}$ After transient forebrain ischemia, increasing miR-29a protects astrocytes and then indirectly neurons. miR-29a leads to decreasing PUMA (p53 upregulated modulator of apoptosis) levels and thereby preserves astrocyte GLT-1 leading to attenuation of oxidative stress and survival of neurons..$^{22}$

Overexpression of miR-223 attenuates NMDA-induced calcium influx in hippocampal neurons and protects the ischemic brain from excitotoxic neuronal cell death through suppression the levels of the glutamate receptor-2 (GluR2) and NMDA subunit NR2B ${ }^{53}$ It has been reported that the NR2A is a target for miR-125b and this miRNA negatively regulates NR2A expression. ${ }^{54}$ It has been approved that activation of NR2B-containing NMDA receptors leading to excitotoxicity and apoptosis. While, activation of the NR2A-containing NMDA receptors exerts a neuroprotective effects and promotes neuronal survival against excitotoxic-mediated neuronal damage. ${ }^{44}$ Synaptic plasticity that is profoundly influenced by the NMDA receptor subunit is altered. ${ }^{54}$ This is a devastating effect because, after stroke damage plasticity can promote adult brain recovery. ${ }^{55-58}$

\section{Post-ischemic oxidative stress}

Oxidative stress results from increased reactive oxygen/nitrogen species (ROS/RNS) and/or decrease of the anti-oxidative stress defense systems of the body. ${ }^{59}$ Several mechanisms caused formation of free radicals and ROS during ischemia, ${ }^{60}$ including high stimulation of NMDA glutamate receptors due to excitotoxicity, ${ }^{61} \mathrm{Ca}^{+}{ }^{+}$overload, mitochondrial dysfunction, ${ }^{62-64}$ neuronal nitric oxide synthase (nNOS) activation, ${ }^{65}$ and migration of inflammatory cells such as neutrophils and leukocytes that can generate superoxide anions. ${ }^{66}$ Oxidative stress has been involved in a variety of diseases, including cancer, atherosclerosis, neurodegenerative diseases, and stroke. ${ }^{67}$ Oxidative damage is a fundamental mechanism of brain damage and neuronal cell death during ischemic stroke. The brain is very susceptible to oxidative stress due to its highly oxygenated environment, with high levels of peroxidisable lipids, low levels of antioxidants and a high iron content. ${ }^{68}$

The activity of antioxidant and detoxifying enzymes such as superoxide dismutase (SOD), glutathione peroxidase, glutathione reductase and Glutathione-S-transferase (GST), has been studied in stroke patients, and these enzymes maintain redox homeostasis and influence the inflammatory response. ${ }^{69,70}$ SOD enzymes (manganese SOD [MnSOD] and extracellular SOD) help brain recovery following ischemic reperfusion injuries. ${ }^{71,72}$ The genes that encode these antioxidant enzymes bear an antioxidant response element (ARE) within their promoters. The transcriptional activation of ARE is mainly regulated by nuclear factor erythroid-2 related factor 2 (Nrf2). ${ }^{73}$ It has been determined that Nrf2 has a neuroprotective activity against stroke injuries, such as oxidative glutamate excitotoxicity, hydrogen peroxide $\left(\mathrm{H}_{2} \mathrm{O}_{2}\right)$ exposure, and $\mathrm{Ca}^{2+}$ overload situations. ${ }^{74}$ Moreover, Nrf2 expression is upregulated at the gene and protein levels in ischemic brains especially in the ischemic penumbra zone; these findings indicate that Nrf2 activation is valuable and might subsequently contribute to cell protection and survival. ${ }^{75}$

\section{MicroRNAs and ischemic oxidative stress}

miRNAs have been observed to be involved in the posttranscriptional regulation of Nrf2 levels. It is discovered that 85 miRNAs can bind to cytoplasmic Nrf2 mRNA to affect its translation. ${ }^{76}$ Studies demonstrated that miR-424 reduced malondialdehyde (MDA) levels, $\mathrm{ROS}$ and abrogated $\mathrm{H}_{2} \mathrm{O}_{2}$-induced injury in neurons which resulted in the neuroprotection against ischemic oxidative damages. ${ }^{77}$ Evaluation the role of miR-93 in cerebral ischemia injuries indicate that miR-93 directly binds to the predicted 3 '-UTR target sites of the Nrf2 genes, and then attenuate the expression of Nrf2 and heme oxygenase-1 ( $\mathrm{HO}-1) .{ }^{78}$ The Nrf2/HO-1 pathway is an important cellular defense mechanism against oxidative stress induced following ischemia/reperfusion. ${ }^{79}$ Also, it is revealed that increasing of Nrf2 levels causes upregulation of SOD enzymes. ${ }^{80,81}$

Recent studies showed that vagus nerve stimulation (VNS) initiated after ischemic stroke in rats which improved the neurological outcomes, reduced ischemic lesion volume, and inhibited inflammatory cytokines.$^{82}$ It is known that miR-210 is involved in the VNS-regulated oxidative stress responses follow- 
Table 2. Specific target genes of miRNAs involved in ischemic stroke pathogenesis

\begin{tabular}{|c|c|c|c|}
\hline miRNA & Main target genes & Function of miRNA & Ref. \\
\hline miR-107 & GLT-1 & Glutamate accumulation & 50 \\
\hline miR-29a & PUMA & Preserves astrocyte GLT-1 & 52 \\
\hline miR-223 & GluR2 & Attenuates NMDA-induced calcium influx & 53 \\
\hline $\operatorname{miR}-223$ & NR2 $B^{*}$ & Attenuates NMDA-induced calcium influx & 53 \\
\hline $\operatorname{miR}-125 b$ & $N R 2 A^{*}$ & Excitotoxic neuronal damage & 54 \\
\hline $\operatorname{miR}-424$ & MDA & Prevents oxidative damages & 77 \\
\hline miR-93 & Nrf2 & Upregulation of SOD enzymes & 78,80 \\
\hline miR-106b-5p & MDA and MnSOD & Protection against oxidative damages & 84 \\
\hline miR-145 & SOD & Increasing oxidative damages & 31 \\
\hline miR-101 & $\operatorname{cox} 2$ & ROS production & 54 \\
\hline miR-146a & COX-2 & ROS production & 88 \\
\hline miR-let-7c-5p & Caspase 3 & Neuroprotection against inflammation & 117 \\
\hline $\operatorname{miR}-181 c$ & TLR4 & $\mathrm{NF}-\kappa \mathrm{B}$ activation & 126 \\
\hline miR-181c & $N F-\kappa B$ & Expression of pro-inflammatory genes & 126 \\
\hline miR-155 & SOCS1, MyD88 & Upregulation of TLR4 & 127 \\
\hline miR-181c & TNF- $\alpha$ & Decreasing neuronal apoptosis & 131 \\
\hline miR-let-7c & iNOS, TNF- $\alpha$ and IL-6 & Decreasing inflammation & 132 \\
\hline miR-181a & IL1- $\alpha$ & Anti-inflammatory effect & 133 \\
\hline miR-146a & IL-1 $\beta$ and IL-6 & Anti-inflammatory effect & 88 \\
\hline miR-491-5p & MMP-9 & Inhibit cellular invasion & 137 \\
\hline miR-25 & FasL & Apoptosis inhibition & 153 \\
\hline miR-29 & FAP-1 & Induction of Fas receptors & 154 \\
\hline miR-21 & FasL & Apoptosis inhibition & 155 \\
\hline miR-99a and miR-let-7c-5p & Caspase-3 & Preventing neural apoptosis & 117,158 \\
\hline miR-9 & $\mathrm{Bcl} 2 \mathrm{~L} 11^{+}$ & Decreasing neuronal apoptosis & 159 \\
\hline miR-106b-5p & $\mathrm{Mcl}-1^{+}$ & Decreasing neuronal apoptosis & 84 \\
\hline $\operatorname{miR}-497$ & $\mathrm{Bcl}-2^{+}$and $\mathrm{Bcl}-\mathrm{w}^{+}$ & Increasing neuronal cell death & 152 \\
\hline miR-181a & $\mathrm{Bcl}-2^{+}$ & Astrocyte dysfunction & 163 \\
\hline miRNA-384-5p and miRNA-494 & $\mathrm{Bcl}-2^{+}$ & Increasing neuronal cell death & 164 \\
\hline miR-134 & $\mathrm{Bcl}-2^{+}$ & Alleviates ischemic injury & 165 \\
\hline miR-134 & HSPA12B & Increasing neuronal apoptosis & 166 \\
\hline miR-124 & iASPP & Promotes neuronal apoptosis & 170 \\
\hline Anti-miR-103-1 & $\mathrm{NCX} 1$ & Cellular calcium and sodium homeostasis & 189 \\
\hline miR-181a antagomir & $N F-\kappa B$ & Decreasing brain ischemia injury & 190 \\
\hline miR-145 antagomir & SOD2 & Inhibition of oxidative stress & 31 \\
\hline miR-Let7f antagomir & IGF-1 & Neuroprotection & 202 \\
\hline miR-134 antagomir & BDNF & Neurogenesis & 165 \\
\hline miR-21 & Wnt and TGF- $\beta$ & NPC regulation & 212 \\
\hline miR-34a & $\begin{array}{l}\text { Notch, Wnt, Hedgehog and } \\
\text { TGF- } \beta\end{array}$ & NPC regulation & 212 \\
\hline miR-124 & Sox9 & Promoting neural differentiation & 213 \\
\hline $\operatorname{miR}-124 a$ & JAG1/Notch & Neurogenesis inhibition & 214 \\
\hline miR-210 & VEGF & Promoting angiogenesis & 204 \\
\hline
\end{tabular}


Table 2. Continued

\begin{tabular}{|c|c|c|c|}
\hline miRNA & Main target genes & Function of miRNA & Ref. \\
\hline miR-15a & FGF2 & Suppress post-stroke angiogenesis & 227 \\
\hline miR-16, $-20 a$ and $-20 b$ & VEGF & Anti-angiogenic agent & 229 \\
\hline miR-130a & GAX and HOXA5 & Promoting angiogenesis & 232 \\
\hline miR-221 and miR-222 & KIT and e-NOS & Decreasing tube formation & 235 \\
\hline
\end{tabular}

Ref., reference; GLT-1, glutamate transporter-1; PUMA, p53 upregulated modulator of apoptosis; GluR2, glutamate receptor 2; NMD, N-Methyl-D-aspartate; MDA, malondialdehyde; Nrf2, nuclear factor erythroid-2 related factor 2; SOD, superoxide dismutase; MnSOD, manganese SOD; COX2, cyclooxygenase 2; ROS, reactive oxygen species; TLR, Toll-like receptor; SOCS1, suppressor of cytokine signaling 1; MyD88, myeloid differentiation primary response gene 88; TNF, tumor necrosis factor; IL, interleukin; MMP-9, metalloproteinases 9; FasL, Fas ligand; FAP-1, Fas associated protein-tyrosine phosphatase 1; HSPA12B, heat shock protein A12B; iASPP, inhibitory member of the apoptosis-stimulating proteins of p53 family; NCX1, sodium-calcium exchanger-1; IGF-1, insulin-like growth factor 1 ; BDNF, brainderived neurotrophic factor; TGF- $\beta$, transforming growth factor- $\beta$; NPC, neuronal stem cells; Sox9, Sry-Box 9 ; VEGF, vascular endothelial growth factor; FGF2, fibroblast growth factor 2; GAX, Growth arrest-specific homeobox; HOXA5, homeobox A5; KIT, kit ligand; e-NOS, endothelial NOS.

*Glutamate NMDA receptor subunits.

${ }^{\dagger}$ Anti-apoptotic Bcl-2 family.

ing cerebral ischemia through decreasing methane dicarboxylic aldehyde levels and increasing SOD and GSH levels. ${ }^{83}$ In addition, ischemic stroke caused to the down-regulation of SOD and GSH activity and the up-regulation of methane dicarboxylic aldehyde. ${ }^{83}$ It has been determined that acute ischemic stroke caused a significant increase of miR-106b-5p. Therefore, miR-106b-5p antisense oligonucleotides (antagomirs) could have a protective effect against post-ischemic oxidative damages via reducing MDA content and restoration of MnSOD activity. ${ }^{84}$ miR-145 expression suppressed protein levels of SOD2 after ischemic stroke. ${ }^{31}$ miR-23a-3p levels increased transiently following ischemia and reperfusion in mice which reduced the ischemia reperfusion and oxidative stress injuries, mechanistically through increasing the expression of MnSOD, and reducing RNS production such as NO and 3-NT levels. ${ }^{85}$

During cerebral ischemia, cyclooxygenase 2 (COX2) can produce ROS. ${ }^{86}$ COX2 is a qualified target of miR-101. ${ }^{54}$ In the normal situation COX2 is little expressed while studies showed that cerebral ischemia readily induced COX2 expression in neuronal cells. ${ }^{87}$ The miR-101 profile in cerebral ischemia is found to be down-regulated. ${ }^{32}$ Also, miR-146a has been found to suppress expression of COX-2 in neurological disorders. ${ }^{88}$ Thus, miRNAs can be considered as a valuable therapeutic agents to antagonize oxidative stress in ischemic stroke.

\section{Post-ischemic inflammation}

Inflammation is an essential step and a secondary injury mechanism in the pathophysiology of cerebrovascular diseases, particularly ischemic stroke. ${ }^{89,90}$ Recent studies demonstrate that post-ischemic neuro-inflammation is an important determining factor for ischemic consequences and its long-term prognoses. ${ }^{91,92}$ In ischemic brain injury, inflammatory responses are triggered as a result of damaged tissue, necrotic cells, debris and ROS. These triggering elements cause microglial activation and release of inflammatory cytokines. ${ }^{93-96}$ Microglia are the resident innate immune macrophages of the CNS, and they are highly activated after brain insult. ${ }^{97-99}$ Activated microglia and their inflammatory factors, such as tumor necrosis factor $\alpha$ (TNF- $\alpha$ ) contribute to the progression of neurodegenerative disorders. ${ }^{100,101}$

Cytokine release leads to post-ischemic inflammation and aggravates primary brain damage. They include, IL-1 $\beta, I L-6$, plasma high sensitivity CRP (hs-CRP) and TNF- $\alpha_{1}$ as well as other potential cytotoxic molecules including NO, ROS, and prostanoids. ${ }^{102-105}$ Microglial suppression can reduce post-ischemic injuries, so this illustrates an attractive therapeutic strategy for ischemic stroke. ${ }^{106,107}$ In addition to cytokines that are expressed in the resident brain cells, there are a peripherally derived cytokines that produce and secrete from T-lymphocytes, mononuclear phagocytes, NK cells and polymorpho-nuclear leukocytes which are involved in ischemic inflammation. ${ }^{108}$

In ischemic brain injury, the expression of a number of pro-inflammatory genes is induced by ROS formation. These genes include nuclear factor- $\kappa \mathrm{B}(\mathrm{NF}-\kappa \mathrm{B})$, interferon regulator factor 1, hypoxia inducible factor 1 (HIF 1) and STAT3. Consequently, these factors upregulate cytokines and expression of adhesion molecules such as intercellular adhesion molecule 1 (ICAM-1), P-selectin and E-selectin. These Cellular adhesion molecules (CAMs) facilitate leukocyte adhesion to the microvascular endothelium in the cerebral ischemic area. ${ }^{107} \mathrm{NF}-\kappa \mathrm{B}$ is a heteromeric transcription factor involved in the activation of pro-inflammatory genes, such as TNF- $\alpha$, ICAM- 1 , COX- 2 , iNOS and IL-6. ${ }^{109,110}$ CAMs are upregulated in the first days of isch- 
emic stroke and are responsible for the migration of the leukocytes through the brain endothelial cells. ${ }^{111}$

During ischemia, neutrophils that are recruited to the ischemic tissue produced the MMPs to infiltrate the blood brain barrier (BBB). Two main group of MMPs are including MMP-9 and MMP-2, and they are responsible for disruption of BBB and hemorrhagic transformation following ischemic stroke. ${ }^{112,113}$

\section{MicroRNAs and ischemic inflammation}

It has been clarified that a number of miRNAs target several genes that are involved in post-ischemic inflammation. ${ }^{114,115}$ Studies showed that miR-424 has a protective effect against ischemic cerebral injuries by mechanisms that inhibit microglia activation. ${ }^{116}$ Also, miR-let-7c-5p have a protective effect against cerebral ischemia neuro-inflammation via inhibition of microglial activation and translational repression of caspase 3. ${ }^{117}$ Overexpression of miR-124 could promote quiescence of microglia and deactivation of macrophages via the C/EBP- $\alpha$ PU.1 pathway. miR-124 expression in the microglia was lessened during the neurological disease. ${ }^{118}$

Ischemic inflammatory process may be the resulted of activation of Toll-like receptors (TLRs). TLRs are a family of receptors that are expressed by microglia and astrocytes. ${ }^{119-121}$ TLRs can activate NF- $\kappa B$ which induces the expression of pro-inflammatory genes, cytokines and adhesion molecules. ${ }^{122}$ Thirteen TLRs have been identified, and TLR4 signaling contributes to post-ischemic inflammatory injuries. ${ }^{123,124}$ In response to hypoxia, TLR4 expression is upregulated in the surface of microglia cells. ${ }^{125}$ It is determined that miR-181c negatively regulates TLR4 expression through its 3'-UTR. Furthermore, miR-181c suppresses NF- $\mathrm{KB}$ activation and its pro-inflammatory products including TNF- $\alpha$, IL-1 $\beta$, and iNOS. ${ }^{126}$ In ischemic cerebral tissue, miR-155 induces the expression of TNF- $\alpha$ and IL- $1 \beta$ via upregulation of TLR4 and downregulates the expression of inflammatory mediators such as suppressor of cytokine signaling 1 (SOCS1) and the myeloid differentiation primary response gene 88 (MyD88). ${ }^{127}$ In the microglia, macrophages and monocytes, expression of the miR-155 was upregulated in response to the pro-inflammatory stimuli such as IFN- $\gamma$ and TNF- $\alpha$. $^{128-130}$

It has been shown that miR-181c can directly regulate post-transcriptional production of TNF- $\alpha$ in the microglia. Therefore, miR-181c decreased release of TNF- $\alpha$ from the microglial cells and decreased neuronal apoptosis. ${ }^{131}$ Also, recent studies suggest that miR-let-7c decreases the expression of macrophages inflammatory genes including iNOS, TNF- $\alpha$ and IL-6. ${ }^{132}$ miR-181a has an anti-inflammatory effect via direct downregulation of IL1- $\alpha$ in monocytes and macrophage cell lines. ${ }^{133} \mathrm{miR}-146 \mathrm{a}$ has been found to suppressed expression of
IL-1 $\beta$ and IL-6 which are pro-inflammatory cytokines. This finding indicates an important role of miR-146a in an inflammation associated with neurological disorders. ${ }^{88}$ During cerebral ischemia, miR-146 is down-regulated..$^{32}$ anti-inflammatory cytokines such as IL-10 post transcriptionally regulated by miR-106a. ${ }^{134}$ Moreover, in the microglia and macrophages miR106a and miR-124 leading to increasing in IL-10 and TGF- $\beta$ respectively. ${ }^{118,134,135}$ Other findings indicate that serum miR124, miR-9 and miR-219 were decreased in acute ischemic stroke thus the neuro inflammatory response and neuronal cell death was facilitated. ${ }^{136}$ miR-491-5p was indicated to decrease the levels of MMP-9 expression and inhibit cellular invasion. ${ }^{137}$ So, correlations between serum levels of miR-124, miR-9, miR219, hs-CRP, MMPs and infarct volume in the acute phase of stroke were determined. ${ }^{136,138,139}$

\section{Post-ischemic cell death}

Apoptosis, necrosis and necroptosis are three types of cell death involved in ischemic stroke pathogenesis. Apoptosis is programmed cell death and it is well known to be activated during development, physiological cellular turnover, and in pathological conditions such as stroke. ${ }^{140-142}$ The apoptotic response is activated either by extrinsic or intrinsic stimuli; the intrinsic stimuli triggered through the mitochondrial signaling pathway; the extrinsic stimuli activated via cell surface death receptors, including TNF- $\alpha$, Fas (CD95/AP01) and TNF related apoptosis inducing ligand (TRAIL) receptors. ${ }^{143,144}$ The extrinsic pathway is activated by ligand-receptor interactions via the external signal. Ligands such as TNF- $\alpha$ and Fas ligand (FasL) bind to TNF-receptor and Fas receptor (FasR) respectively which initiates formation of death inducing signaling complex and caspase- 3 activation. ${ }^{145}$ Both pathways are interface at the point of caspase- 3 activation which results to the mitochondrial membrane permeabilization, chromatin condensation, DNA fragmentation, and eventually cell death. ${ }^{146}$

Cerebral ischemia caused cytotoxic accumulation of intracellular $\mathrm{Ca}^{2+}$ through the stimulation of NMDA and AMPA glutamate receptors. Increased intracellular calcium activates calpains resulting in the cleavage of $\mathrm{Bcl}-2$ interacting domain to truncated Bid (tBid). ${ }^{147}$ At the mitochondrial membrane, tBid forms heterodimers by interaction with pro-apoptotic proteins such as Bad-Box and opens the mitochondrial transition pores which promote releasing of mitochondrial cytochrome c (Cytc) or apoptosis inducing factor (AIF). ${ }^{148}$ The released Cytc in the presence of adenosine triphosphate (ATP)/deoxy ATP binds to the apoptotic protease activating factor 1 and procaspase- 9 to form an apoptosome which activates caspase- 9 and subsequently caspase- 3 . Activated caspase- 3 cleaves nDNA repair 
enzymes, which leads to nDNA damage and apoptotic cell death. Furthermore, AIF is translocated to the nucleus and initiates large-scale (50 kb) DNA fragmentation and cell death in a caspase-independent manner. ${ }^{149}$ After focal ischemic stroke caspase activation is present in the penumbra zone, an ischemic high risk area, and hence inhibition of caspase can protect against focal ischemia injuries. ${ }^{150}$

\section{MicroRNAs and ischemic apoptosis}

Several studies showed that expression and function of specific miRNAs could regulate post-ischemic neural death by altering the expression of the target genes. ${ }^{151,152}$ miR-25 could modulate cerebral ischemia/reperfusion damage by downregulation of the Fas/FasL Pathway and apoptosis inhibition. ${ }^{153}$ miR-29 was found to repress expression of Fas associated protein-tyrosine phosphatase 1 which is the inducer of the FasRs. ${ }^{154}$ miR29 was demonstrated to be up-regulated during cerebral ischemia in rat models. ${ }^{32}$ Some evidence showed that miR-21 can target Fas-ligand and protect neurons from apoptosis during ischemia. ${ }^{155} \mathrm{Fas} /$ FasL belong to the TNF receptor/ligand superfamily of co-stimulatory molecules and play an essential role in the induction of apoptosis. ${ }^{156}$

miR155 regulates various functions of cells and its knockdown could modulate apoptosis via regulating caspase-3 gene expression. ${ }^{157}$ Other findings indicate that miR-99a suppressed both pro-caspase- 3 and activated caspase- 3 expression as well as preventing neural apoptosis following cerebral ischemic stroke. ${ }^{158}$ miR-let-7c-5p has been reported to repress caspase 3 that led to protective effects against cerebral ischemia. ${ }^{117}$ miR9 expression could specifically regulate Bcl2L 11 translation which led to decreasing cell apoptosis, also miR-9 is able to restore the neurological scores and behavioral abnormalities. However, in the ischemic brain, miR-9 expression was downregulated and reversing its level could rescue the abnormalities and cell apoptosis. ${ }^{159}$ In response to different stimuli, Bcl2L11 is produced and can induce apoptosis by inactivating anti-apoptotic $\mathrm{Bc} 22$ proteins and activating BAX-BAK1. ${ }^{160,161} \mathrm{Bcl}-2$ and $\mathrm{BCl}-\mathrm{xl}$ proteins are a key regulators in lessening post-ischemic apoptotic and cell death. ${ }^{162}$

Following acute ischemic stroke, miR-106b-5p increased significantly and directly target the Mcl-1 protein which is a member of Bcl-2 family and a key regulator of apoptosis after DNA damage. ${ }^{84}$ So, miR-497 increased ischemic neuronal cell death by negatively regulating anti-apoptotic proteins, such as $\mathrm{Bcl}-2$ and $\mathrm{Bcl}-\mathrm{w} .{ }^{152}$ Several reports demonstrated that miR181a levels, decreased $\mathrm{Bcl}-2$ proteins and increased evidence of astrocyte dysfunction. ${ }^{163}$ Expression profiles of microRNAs following cerebral ischemia suggest that differentially ex- pressed miRNA-384-5p and miRNA-494 caused $\mathrm{Bcl}-2$ to significantly decreased. ${ }^{164}$ Moreover, Downregulation of miR-134 alleviates ischemic injury through enhancing the Bcl-2 expression in neurons following oxygen glucose deprivation. ${ }^{165}$ It is reported that miR-134 plays a critical role in the post-ischemic apoptosis and cell death through negatively modulating HSPA12B protein expression in a posttranscriptional manner. ${ }^{166}$ HSPA12B is a member of the HSP70 family, and overexpression of this protein decreased apoptosis in the ischemic brain tissue. ${ }^{167,168}$ Furthermore, it has been demonstrated that downregulation of the miR-125b expression caused increasing p53 expression which acts as apoptosis mediator by the intrinsic pathway. In ischemic rats, miR-125b is down-regulated following reperfusion. ${ }^{169}$ Also, miR-124 can downregulate the inhibitory member of the apoptosis-stimulating proteins of p53 family (iASPP), and promotes neuronal apoptosis after cerebral ischemia. Therefore, suppression of miR-124 could be a novel mechanism for non-transcriptionall regulation of neuronal apoptosis in focal cerebral ischemia. ${ }^{170}$ ASPP family consists of 3 members: ASPP1, ASPP2, and iASPP, because they bind to the proteins such as $\mathrm{Bcl}-2$ and RelA/p65 as key players in controlling apoptosis. ${ }^{171}$ As mentioned in the previous paragraphs, VNS improved the neurological outcomes and reduced ischemic lesion volume after cerebral ischemia in rats. Therefore, VNS exerts neuroprotective effects against ischemic injuries potentially through anti-apoptotic activity of miR-210 which is mediated by hypoxia-inducible factor and Akt-dependent pathways. $^{83}$ Following brain ischemia the up-regulation of miR-323 promoted apoptosis and suppressed survival, whereas the inhibition of miR-323 could be a good agent for the prevention and therapy of cerebral ischemic injury..$^{172}$ Consequently, these microRNAs maybe involved in neuronal apoptosis during stroke.

\section{MicroRNAs as possible therapeutic agents}

The underlying pathophysiology of stroke is highly complicated, consisting of numerous pathological processes such as excitotoxicity, oxidative stress, inflammation and apoptosis. Currently, effective treatment for ischemic stroke is limited to recombinant tissue plasminogen activator (tPA). ${ }^{173}$ tPA is the only appropriate thrombolytic agent available for acute ischemic stroke treatment. ${ }^{174,175}$ However, tPA is limited by its narrow therapeutic window, which can only be given up to 6 hours after onset of stroke, therefore, making it suitable to only a minority (less than 10\%) of stroke patients. ${ }^{176}$ Also, beside its beneficial thrombolytic role, tPA has deleterious effects includ- 
ing intracranial hemorrhage, ${ }^{177}$ and neurotoxicity. ${ }^{178}$ In addition, studies showed that inhibition of tPA with plasminogen activator inhibitor-1 or neuroserpin have neuroprotective effects against ischemic brain damage. ${ }^{179,180}$ Other alternative treatments include the use of other anti-thrombotic agents, mechanical thrombectomy and anti-platelet agents such as aspirin. ${ }^{181}$ As noted, there are many limitations of thrombolytic treatment for stroke. Therefore, there is continuing research for novel therapeutic agents. miRNAs have remarkable potential as they are endogenous molecules that are capable of controlling the expression of potentially deleterious genes. Furthermore, miRNAs can regulate the genes that contribute in the neuroprotection, neurogenesis and angiogenesis which leading to enhancing recovery and repair mechanisms in ischemic stroke patients (Figure 3, Table 2).

\section{MicroRNAs and neuroprotection}

Neuroprotective strategies that limit secondary tissue loss and/ or improve functional outcomes have been identified to help clinicians in decreasing stroke mortality rates and improving the quality of patient's life. ${ }^{182}$ Glutamate antagonists are the most studied neuroprotective agents. Glutamate is a major excitatory neurotransmitter in the CNS and is released excessively during ischemia. ${ }^{183}$ miRNAs seem to offer some potential to attenuate excitotoxicity and miR-125b and miR-223 have been demonstrated to target NMDA receptor subunits includ- ing NR2A and NR2B, respectively, and negatively regulate their expression. ${ }^{53,54}$ Hence, increasing the expression of this miRNAs represents a potential therapeutic application through decreasing the effects of excitotoxicity, which needs to be further investigated.

Calcium influx during ischemic stroke triggered intracellular destructive enzymes, which leads to brain tissue damage. ${ }^{184}$ Interestingly, the sodium-calcium exchanger-1 (NCX1) gene expression is influenced by cerebral ischemia, which is a plasma membrane transporter that regulates cellular calcium and sodium homeostasis in the brain. ${ }^{185-187}$ NCX activation ameliorates the consequences of ischemic brain damage. ${ }^{188}$ So, it has been showed that anti-miR-103-1 exerts a strong neuroprotective effect against ischemic damage through NCX1 activation and offers the opportunity to develop a new therapeutic strategy for ischemic stroke. ${ }^{189}$ Neuroprotection could also be achieved by targeting the inflammatory mediators that contribute to brain injury following ischemic stroke. miR-181a has deleterious effects on ischemic stroke, and using miR-181a antagomir caused neuroprotective effects, reduced NF- $\mathrm{B} B$ activation and improved neurological deficits in mice. ${ }^{190}$ Furthermore, the ability to decrease brain ischemia injury (both focal and forebrain ischemia) makes miR-181a antagomir a therapeutic agent. ${ }^{163}$ It has been shown that suppression of TLR4, which is mediated by miR-181c, could be neuroprotective in hypoxic injuries, so this offers a potential therapeutic agent for isch-

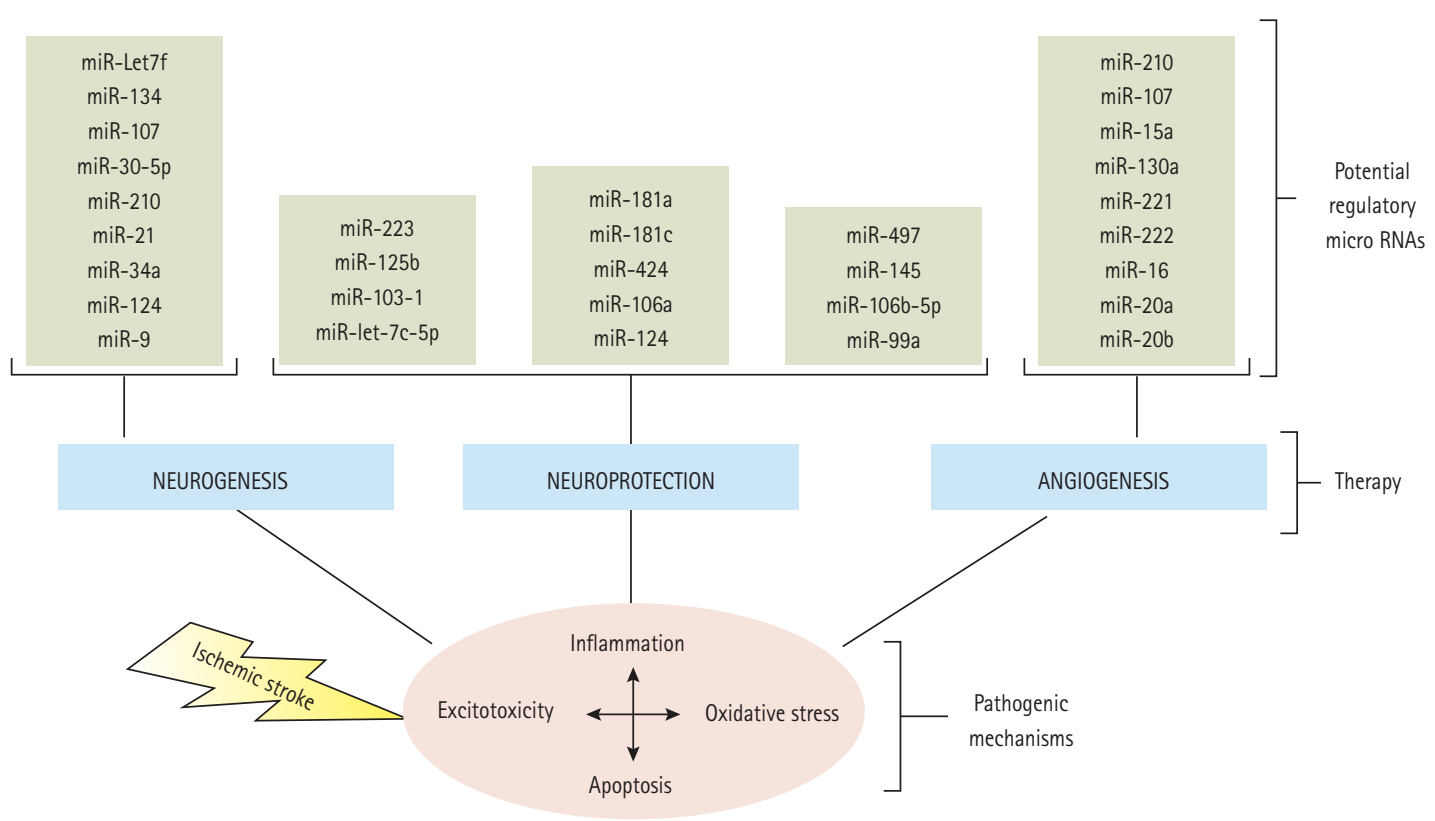

Figure 3. Overview of processes involved in ischemic stroke and high potential therapeutic microRNAs. Cerebral ischemia includes several injurious mechanisms (excitotoxicity, oxidative stress, inflammation and apoptosis) to confer neuronal injury. Potential therapeutic areas to compensate for these pathogenic process include promoting angiogenesis, neurogenesis and neuroprotective recovery and repair mechanisms. 
emic stroke associated with microglial activation. ${ }^{126}$ Studies showed that miR-424 overexpression has a neuroprotective effect on cerebral ischemia injury through mechanisms relating to the preventing of microglia activation. ${ }^{116}$ In the microglia and macrophages miR-106a and miR-124 leading to increasing in IL-10 and TGF- $\beta$ respectively. ${ }^{118,134,135}$ In turn, IL-10 and TGF- $\beta$ inhibit expression of adhesion molecules in endothelial cells and production of pro-inflammatory cytokines. ${ }^{191,192}$ Therefore, TGF- $\beta$ and IL-10 are neuroprotective factors against neuro-inflammation. ${ }^{193-195}$

As mentioned in the other sections, during ischemic stroke, there is increased production of reactive oxygen free radicals due to glutamate excitotoxicity. ${ }^{196}$ Accordingly, the free radical scavengers potentially have neuroprotective roles. Preclinical studies in animal models that using those agents presented effectiveness in reducing neurological injuries. ${ }^{197}$ miR-497 increased ischemic neuronal cell death with negatively regulating anti-apoptotic proteins, such as $\mathrm{Bcl}-2$ and $\mathrm{Bcl}-\mathrm{w}^{152}$ Antagonism of miR-497 leading to decreasing in the infarct volume due to ischemia in mice. ${ }^{152}$ Some studies have shown that increasing Nrf2 activity is highly neuroprotective against ischemic consequences. ${ }^{74,198}$ It has been shown that miR-145 antagomir increased protein levels of SOD2 after ischemic stroke. $^{31}$ It is determined that miR-106b-5p antagomir can protect against cerebral ischemia/reperfusion (I/R) injury by inhibition of apoptosis and oxidative stress. ${ }^{84}$ Other studies indicate that miR-99a and miR-let-7c-5p have neuroprotective effects through inhibition of pro-caspase- 3 and caspase- 3 expressions as well as preventing apoptosis following cerebral ischemic stroke. ${ }^{158}$ Sequestration of this miRNA could therefore serve as a potential defense against post-stroke pathogenic processes in neuroprotection therapy.

\section{MicroRNAs and neurogenesis}

Neurotrophic factors are small polypeptide molecules, which are involved in cell proliferation, migration, differentiation and development of the nervous system. In the adult CNS, neurotrophic factors have important roles in the survival and maintenance of neuronal cells by activating cell survival genes and inhibition of suicide genes. ${ }^{199}$ For this reason, deprivation of these factors in the ischemic penumbra zone can trigger neuronal apoptosis and lead to cell death. In preclinical studies, neurotrophic factors such as nerve growth factor, brainderived neurotrophic factor (BDNF), ciliary neurotrophic factor, glialderived neurotrophic factor, vascular endothelial growth factor (VEGF), and insulin-like growth factor 1 (IGF-1) have all been shown to decrease infarct size in animal models. ${ }^{200}$ Ischemic activated microglia can release a variety of cytoprotective sub- stances by producing neurotrophic molecules such as IGF-1, BDNF, and several other growth factors. ${ }^{105,201}$

It has been shown that miR-Let7f antagomir targets the IGF1 signaling for translation activation which could alternatively promote IGF-1-like neuroprotection in the ischemic stroke models. ${ }^{202}$ Downregulation of miR-134 alleviates ischemic injury through enhancing of BDNF and Bcl-2 expression in neurons following oxygen glucose deprivation. Therefore, miR-134 antagomir providing a potential therapeutic agent for cerebral ischemic injury. ${ }^{165}$ miR-107 and miR-30-5p are reported as BDNF regulators and investigations into the precise mechanism of both these miRNAs in BDNF regulation can be a potential therapeutic agent in neuroprotection. ${ }^{203}$ Overexpression of miR-210 can induce neurogenesis in the adult mouse brain, which is associated with VEGF upregulation. ${ }^{204}$ VEGF is an important neurogenic factor with therapeutic potential in ischemic stroke. ${ }^{205}$

Following cerebral ischemia, neuronal stem and precursor cells (NSC and NPC) can be activated and migrate to the injured areas. ${ }^{206}$ Hedgehog, Notch, Wnt and TGF- $\beta$ signaling pathways are found to be responsible for proliferation, migration and differentiation of NSC and NPC to promote neuronal repair after ischemic stroke. ${ }^{207-211}$ miR-21 was found to be significantly upregulated following cerebral ischemia, and it could act as a NPC regulator by Wnt and TGF- $\beta$ signaling pathways. Furthermore, miR-34a may negatively regulate the NPC proliferation by inhibiting Notch, Wnt, Hedgehog and TGF- $\beta$ signaling pathways following brain ischemia. ${ }^{212}$ It has been reported that increased miR-124 concentrations could promote neural differentiation by post-transcriptionally downregulation of Sry-Box 9 (Sox9). It is demonstrated that Sox9 overexpression abolished neuronal differentiation, whereas Sox9 knockdown led to improved neuron formation. ${ }^{213}$ miR-124a was found to inhibit neurogenesis following stroke through targeting the JAG1/Notch signaling pathway. miR-124a in neural progenitor cells decreased JAG1 transcript and protein levels significantly, which causing to inactivation of Notch signals. ${ }^{214}$ Furthermore, this microRNA was reported to be constitutively expressed in the brain mature neurons. ${ }^{215}$ miR-9 has been revealed to limit migration and promote proliferation in human neuronal progenitor cells and its downregulation permits to neuronal migration. ${ }^{215}$ Therefore, pharmacological regulation of these miRNAs could be a potential agent in the post-ischemic neurogenesis.

\section{MicroRNAs and angiogenesis}

Angiogenesis is an important, beneficial event occurring in ischemic stroke. Angiogenesis delivers blood flow and metabolism to ischemic tissue and is positively correlated with the 
survival rate of stroke patients. ${ }^{216}$ miRNAs that regulate the process of angiogenesis have been offered as a potential treatment strategy for ischemic stroke. ${ }^{217}$ Overexpression of miR210 promotes focal angiogenesis in the adult mouse brain, which was associated with local increased VEGF levels. ${ }^{204}$ Also, miR-210 can trigger vascular endothelial cell migration and tube formation under hypoxia in vitro. ${ }^{204}$ Overexpression of miR-210 in patients with acute ischemic stroke show better clinical outcomes. ${ }^{218}$ Hence, miR-210 is specifically sensitive to hypoxic stimuli in almost all of cells, ${ }^{219}$ and its expression is enhanced by hypoxia-related transcription factors, such as HIF- $1 \alpha{ }^{220,221}$ miR-92a regulates angiogenesis targeting several proangiogenic proteins, including the integrin subunit alpha5. Thus, miR-92a could be a therapeutic target in the setting of ischemic disease. ${ }^{222}$

VEGF is an essential angiogenic factor with therapeutic potential in ischemic stroke. ${ }^{223,224}$ It has been demonstrated that miR-107 contributes to post-stroke angiogenesis by directly down regulation of Dicer-1 expression which is a gene that encodes an important enzyme in the miRNA processing. This leads to translational de-suppression of VEGF mRNA, thereby increasing expression of VEGF (VEGF165/NEGF164), resulting in post-stroke angiogenesis. ${ }^{225}$ miR-107 expression is regulated by HIF- $1 \alpha$ and has binding sites with HIF- $1 \alpha .{ }^{226} A$ novel finding indicates that overexpression of miR-15a in endothelial cells can suppress post-stroke angiogenesis via direct inhibition of endogenous endothelial fibroblast growth factor 2 and VEGF activities. ${ }^{227}$ Also, studies have shown that expression of the miR-15a is significantly increased in the cerebral vasculature at the penumbral zone following cerebral ischemia. ${ }^{228}$ Furthermore, miR-16, -20a and -20b have been found to target VEGF and act as an anti-angiogenic agent in cultured endothelial cells.229

Growth arrest-specific homeobox (GAX) and homeobox A5 (HOXA5) are anti-angiogenic transcription factors and are involved in the inhibition of endothelial cell function. GAX is expressed in the endothelial cells and inhibits angiogenesis through down regulation of NF-kB signaling pathway. ${ }^{20,231}$ miR-130a has been found to down-regulate GAX and HOXA5 expression, consequently antagonizing the antiangiogenic activity of these factors. ${ }^{232}$ miR-221 and -222 were found to inhibit angiogenesis by interaction and down-regulation of kit ligand (KIT), and enriched of this microRNAs in the hippocampus of the mice indicates a possible role for them in stroke pathogenesis. ${ }^{233,234}$ In the same way, it was suggested that miR-221 and miR-222 decreases tube formation and migration by targeting both KIT and endothelial NOS. ${ }^{235}$ Therefore, pharmacological modulation of these miRNAs could be a promising ther- apeutic approach for angiogenesis after ischemic stroke.

\section{Challenges for miRNA therapy}

There is mounting evidence that miRNA-based therapies hold great promise. However, despite the exciting potential of miRNAs, critical hurdles remain to be overcome which often include delivery of miRNA-targeting agents. Other limitations including limited in vivo stability, limited tissue distribution, and untoward side effects. Although, either viral vectors and nonviral delivery systems such as liposomes could overcome these challenges, both liposomes and viral vectors may be toxic and/ or immunogenic which would restrict their clinical application. Liposomes are utilized to deliver small interference RNAs (siRNA). However, synthetic systems such as liposomes have relatively lower yield compared to viral vectors. ${ }^{236,237}$

After stroke, a high level of miRNAs leads to inhibition of the expressions of many genes. Therefore, inhibition of these miRNAs may be a therapeutic targets for ischemic stroke. ${ }^{238}$ There are several tools to decrease the level of miRNA such as antagomir (anti-sense oligonucleotide), which blocks miRNA silencing activity by complimentary binding to the mature miRNA, and this could be a useful approach to inhibition of miRNA function. ${ }^{239}$ Therefore, use of an antagomir may be another therapeutic option when upregulated miRNAs are pathogenic.

The advantage of antigomirs is that they can be delivered into cells directly without any vector assistant, because they are nuclease resistant. Therefore, antigomirs avoid the complication of using delivery vehicles. The drawbacks that limit antigomir application as therapeutic reagents in humans are the need for high doses and their possible side-effects. ${ }^{240-242}$

Antagomirs could easily be delivered intravenously, but there is poor distribution in the brain due to the blood-brain barrier, which prevents most exogenous substances from entering the CNS. $^{243,244}$ In recent years, intranasal delivery has been used to target the brain, and evidence shows that olfactory nerve pathways, trigeminal nerve pathways, vascular and lymphatic pathways are involved in intranasal delivery. ${ }^{245}$ Further studies have shown that intranasal delivery of antagomir- miR-206 reached the brain and increased memory function in mice with Alzheimer's mice. ${ }^{246}$

Furthermore, miRNAs have been introduced by mechanical methods such as high pressure injection and electroporation, but these methods cause too much damage to the tissues. ${ }^{247,248} \mathrm{Ad}-$ ministration of miRNAs in the absence of a carrier presents limited tissue distribution, and they are taken up by the liver and kidney and rapidly excreted in urine. In addition, the lethal dosage, LD50, of specific miRNAs has yet to be recognized. ${ }^{236}$ Nevertheless, it is 
probable that an increasing number of these molecules will progress and will eventually be developed to become approved treatment for ischemic stroke in the coming years.

\section{Conclusions}

In this review we have presented evidence that miRNA function is increasingly dysregulated following ischemic stroke, and altering of these molecules has profound effects on the downstream target genes which are involved in the post-ischemic process. A single miRNA exerts its cellular function by mostly inhibition and occasionally activation of numerous downstream mRNA targets. Several studies have attempted to correlate between changes in the expression of miRNAs and postischemic pathogenic processes such as excitotoxicity, inflammation, oxidative stress and apoptosis. These studies clarify the contribution of miRNAs in the post-ischemic pathophysiological process and help us to a better understanding of the processes involved in ischemic stroke pathology, where they could be a therapeutic agent. Also, there is accumulating evidence that several miRNAs and their target genes are involved in the retrieval and repair process which including the promotion of angiogenesis, neurogenesis and neuroprotection.

miRNA profiles provide evidence that their modulation could be beneficial for ischemic stroke diagnosis, as well as being potential therapeutic agents. Moreover, the ability of miRNAs to regulate numerous target genes clearly demonstrates their importance in ischemic stroke therapeutics. Finally, the understanding of delivery systems will be a key to bringing miRNA to the clinic as findings from animal models become better refined to allow translation into human therapeutic agents for the treatment of ischemic stroke.

\section{Acknowledgments}

This work was supported by Ahvaz Jundishapur University Grant. The authors declare no financial or commercial conflict of interest.

\section{References}

1. Heron M. Deaths: leading causes for 2004. Natl Vital Stat Rep 2007;56:1-96.

2. Centers for Disease Control and Prevention (CDC). Prevalence of disabilities and associated health conditions among adults--United Sstates, 1999. Morb Mortal Wkly Rep 2001;50:120-125.

3. World Health Organization. The World health report 2004: changing history. Geneva: World Health Organization, 2004.

4. Mukherjee D, Patil CG. Epidemiology and the global burden of stroke. World Neurosurg 2011;76(6 Suppl):S85-S90.

5. Beal CC. Gender and stroke symptoms: a review of the current literature. J Neurosci Nurs 2010;42:80-87.

6. Hatano S. Experience from a multicentre stroke register: a preliminary report. Bull World Health Organ 1976;54:541543.

7. Murphy TH, Li P, Betts K, Liu R. Two-photon imaging of stroke onset in vivo reveals that NMDA-receptor independent ischemic depolarization is the major cause of rapid reversible damage to dendrites and spines. J Neurosci 2008;28:1756-1772.

8. Hossmann KA. Pathophysiology and therapy of experimental stroke. Cell Mol Neurobiol 2006;26:1055-1081.

9. Besancon E, Guo S, Lok J, Tymianski M, Lo EH. Beyond NMDA and AMPA glutamate receptors: emerging mechanisms for ionic imbalance and cell death in stroke. Trends Pharmacol Sci 2008;29:268-275.

10. Bandera E, Botteri M, Minelli C, Sutton A, Abrams KR, Latronico N. Cerebral blood flow threshold of ischemic penumbra and infarct core in acute ischemic stroke: a systematic review. Stroke 2006;37:1334-1339.

11. Baron JC. Mapping the ischaemic penumbra with PET: implications for acute stroke treatment. Cerebrovasc Dis 1999;9:193-201.

12. Jung $S$, Gilgen $M$, Slotboom J, El-Koussy M, Zubler $C$, Kiefer $C$, et al. Factors that determine penumbral tissue loss in acute ischaemic stroke. Brain 2013;136(Pt 12):3554-3560.

13. Bretón RR, Rodríguez JCG. Excitotoxicity and oxidative stress in acute ischemic stroke. In: Rodriguez JCG ed. Acute Ischemic Stroke. Croatia/China: InTech, 2012.

14. Ouyang $Y B$, Voloboueva LA, Xu $\sqcup$, Giffard RG. Selective dysfunction of hippocampal CA1 astrocytes contributes to delayed neuronal damage after transient forebrain ischemia. $J$ Neurosci 2007;27:4253-4260.

15. Xu L, Emery JF, Ouyang YB, Voloboueva LA, Giffard RG. Astrocyte targeted overexpression of HSP72 or SOD2 reduces neuronal vulnerability to forebrain ischemia. Glia 2010;58:10421049.

16. Liu J. Control of protein synthesis and mRNA degradation by microRNAs. Curr Opin Cell Biol 2008;20:214-221.

17. Mocellin S, Pasquali S, Pilati P. Oncomirs: from tumor biology to molecularly targeted anticancer strategies. Mini Rev Med Chem 2009;9:70-80.

18. Johnnidis JB, Harris MH, Wheeler RT, Stehling-Sun S, Lam $\mathrm{MH}$, Kirak 0 , et al. Regulation of progenitor cell proliferation and granulocyte function by microRNA-223. Nature 
2008;451:1125-1129.

19. Aumiller V, Förstemann K. Roles of microRNAs beyond development--metabolism and neural plasticity. Biochim Biophys Acta 2008;1779:692-696.

20. Bushati N, Cohen SM. MicroRNAs in neurodegeneration. Curr Opin Cell Biol 2008;18:292-296.

21. Bartel DP. MicroRNAs: genomics, biogenesis, mechanism, and function. Cell 2004;116:281-297.

22. Bourassa MW, Ratan RR. The interplay between microRNAs and histone deacetylases in neurological diseases. Neurochem Int 2014;77:33-39.

23. Lee $Y$, Jeon $K$, Lee JT, Kim S, Kim VN. MicroRNA maturation: stepwise processing and subcellular localization. EMBO J 2002;21:4663-4670.

24. Basyuk E, Suavet F, Doglio A, Bordonné R, Bertrand E. Human let-7 stem-loop precursors harbor features of rnase iii cleavage products. Nucleic Acids Res 2003;31:6593-6597.

25. Han J, Lee Y, Yeom KH, Kim YK, Jin H, Kim VN. The Drosha-DGCR8 complex in primary microRNA processing. Genes Dev2004;18:3016-3027.

26. Lau NC, Lim LP, Weinstein EG, Bartel DP. An abundant class of tiny RNAs with probable regulatory roles in Caenorhabditis elegans. Science 2001;294:858-862.

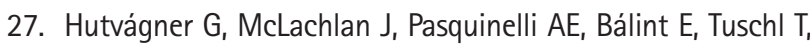
Zamore PD. A cellular function for the RNA-interference enzyme Dicer in the maturation of the let-7 small temporal RNA. Science $2001 ; 293: 834-838$.

28. Chendrimada TP, Gregory RI, Kumaraswamy E, Norman J, Cooch N, Nishikura K, et al. Trbp recruits the Dicer complex to ago 2 for microRNA processing and gene silencing. Nature 2005;436:740-744.

29. Jeyaseelan K, Lim KY, Armugam A. MicroRNA expression in the blood and brain of rats subjected to transient focal ischemia by middle cerebral artery occlusion. Stroke 2008;39:959-966.

30. Redell JB, Liu Y, Dash PK. Traumatic brain injury alters expression of hippocampal microRNAs: potential regulators of multiple pathophysiological processes. J Neurosci Res 2009;87:1435-1448.

31. Dharap A, Bowen K, Place R, Li LC, Vemuganti R. Transient focal ischemia induces extensive temporal changes in rat cerebral microRNAome. J Cereb Blood Flow Metab 2009;29:675-687.

32. Liu DZ, Tian $Y$, Ander BP, Xu H, Stamova BS, Zhan $X$, et al. Brain and blood microRNA expression profiling of ischemic stroke, intracerebral hemorrhage, and kainate seizures. J Cereb Blood Flow Metab 2010;30:92-101.

33. Cucchiara B, Nyquist P. Blood markers in tia: array of hope?
Neurology 2011;77:1716-1717.

34. Xu J, Zhao J, Evan G, Xiao C, Cheng Y, Xiao J. Circulating microRNAs: novel biomarkers for cardiovascular diseases. $J \mathrm{Mol}$ Med (Berl) 2012;90:865-875.

35. Jickling GC, Sharp FR. Blood biomarkers of ischemic stroke. Neurotherapeutics 2011;8:349-360.

36. Zhan $X$, Jickling GC, Tian $Y$, Stamova $B, X u H$, Ander $B$, et al. Transient ischemic attacks characterized by RNA profiles in blood. Neurology 2011;77:1718-1724.

37. Ly JV, Zavala JA, Donnan GA. Neuroprotection and thrombolysis: combination therapy in acute ischaemic stroke. Exp Opin Pharmacother 2006;7:1571-1581.

38. Krnjević K. Electrophysiology of cerebral ischemia. Neuropharmacology 2008;55:319-333.

39. Pizzi M, Fallacara C, Arrighi V, Memo M, Spano P. Attenuation of excitatory amino acid toxicity by metabotropic glutamate receptor agonists and aniracetam in primary cultures of cerebellar granule cells. J Neurochem 1993;61:683-689.

40. Mosbacher J, Schopfer R, Monyer H, Burnashev N, Seeburg $\mathrm{PH}$, Ruppersberg JP. A molecular determinant for submillisecond desensitization in glutamate receptors. Science 1994;266:1059-1062.

41. Moriyoshi K, Masu M, Ishii T, Shigemoto R, Mizuno N, Nakanishi S. Molecular cloning and characterization of the rat NMDA receptor. Nature 1991;354:31-37.

42. Mehta SL, Manhas N, Raghubir R. Molecular targets in cerebral ischemia for developing novel therapeutics. Brain Res Rev 2007;54:34-66.

43. Hardingham GE, Fukunaga $Y$, Bading H. Extrasynaptic NMDARs oppose synaptic NMDARs by triggering CREB shutoff and cell death pathways. Nat Neurosci 2002;5:405-414.

44. Liu Y, Wong TP, Aarts M, Rooyakkers A, Liu L, Lai TW, et al. NMDA receptor subunits have differential roles in mediating excitotoxic neuronal death both in vitro and in vivo. J Neurosci 2007;27:2846-2857.

45. Tu W, Xu X, Peng L, Zhong X, Zhang W, Soundarapandian MM, et al. Dapk1 interaction with NMDA receptor NR2B subunits mediates brain damage in stroke. Cell 2010;140:222-234.

46. Martin HG, Wang YT. Blocking the deadly effects of the NMDA receptor in stroke. Cell 2010;140:174-176.

47. Zhou L, Li F, Xu HB, Luo CX, Wu HY, Zhu MM, et al. Treatment of cerebral ischemia by disrupting ischemia-induced interaction of nNOS with PSD-95. Nat Med 2010;16:14391443.

48. Lai TW, Shyu WC, Wang YT. Stroke intervention pathways: NMDA receptors and beyond. Trends Mol Med 2011;17:266275.

49. Jeyaseelan K, Lim KY, Armugam A. Neuroprotectants in 
stroke therapy. Exp Opin Pharmacother 2008;9:887-900.

50. Yang ZB, Zhang Z, Li TB, Lou Z, Li SY, Yang H, et al. Up-regulation of brain-enriched miR-107 promotes excitatory neurotoxicity through down-regulation of glutamate transporter-1 expression following ischaemic stroke. Clin Sci (Lond) 2014;127:679-689.

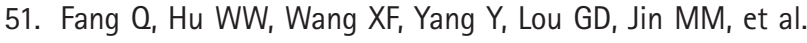
Histamine up-regulates astrocytic glutamate transporter 1 and protects neurons against ischemic injury. Neuropharmacology 2014;77:156-166.

52. Ouyang YB, Xu L, Lu Y, Sun X, Yue $S$, Xiong XX, et al. Astrocyte-enriched miR-29a targets PUMA and reduces neuronal vulnerability to forebrain ischemia. Glia 2013;61:1784-1794.

53. Harraz MM, Eacker SM, Wang X, Dawson TM, Dawson VL. MicroRNA-223 is neuroprotective by targeting glutamate receptors. Proc Natl Acad Sci U S A 2012;109:18962-18967.

54. Edbauer D, Neilson JR, Foster KA, Wang CF, Seeburg DP, Batterton $\mathrm{MN}$, et al. Regulation of synaptic structure and function by FMRP-associated microRNAs miR-125b and miR132. Neuron 2010;65:373-384.

55. Biernaskie J, Chernenko G, Corbett D. Efficacy of rehabilitative experience declines with time after focal ischemic brain injury. J Neurosci 2004;24:1245-1254.

56. Brown $\mathrm{CE}$, Aminoltejari $\mathrm{K}$, Erb $H$, Winship IR, Murphy TH. In vivo voltage-sensitive dye imaging in adult mice reveals that somatosensory maps lost to stroke are replaced over weeks by new structural and functional circuits with prolonged modes of activation within both the peri-infarct zone and distant sites. J Neurosci 2009;29:1719-1734.

57. Brown CE, Li P, Boyd JD, Delaney KR, Murphy TH. Extensive turnover of dendritic spines and vascular remodeling in cortical tissues recovering from stroke. J Neurosci 2007;27:41014109.

58. Carmichael ST, Archibeque I, Luke L, Nolan T, Momiy J, Li S. Growth-associated gene expression after stroke: evidence for a growth-promoting region in peri-infarct cortex. Exp Neur 2005;193:291-311.

59. Beckman KB, Ames BN. Mitochondrial aging: open questions. Ann N Y Acad Sci 1998;854:118-127.

60. Guzik T, Korbut R, Adamek-Guzik T. Nitric oxide and superoxide in inflammation and immune regulation. J Physiol Pharmacol 2003;54:469-487.

61. Cherubini A, Ruggiero C, Polidori MC, Mecocci P. Potential markers of oxidative stress in stroke. Free Radical Bio Med 2005;39:841-852.

62. Coyle JT, Puttfarcken P. Oxidative stress, glutamate, and neurodegenerative disorders. Science 1993;262:689-695.

63. Cuzzocrea S, Riley DP, Caputi AP, Salvemini D. Antioxidant therapy: a new pharmacological approach in shock, inflammation, and ischemia/reperfusion injury. Pharmacol Rev 2001;53:135-159.

64. Lafon-Cazal M, Pietri S, Culcasi M, Bockaert J. NMDA-dependent superoxide production and neurotoxicity. Nature 1993;364:535-537.

65. Piantadosi CA, Zhang J. Mitochondrial generation of reactive oxygen species after brain ischemia in the rat. Stroke 1996;27:327-331; discussion 332.

66. Lipton SA, Rosenberg PA. Excitatory amino acids as a final common pathway for neurological disorders. N Engl J Med 1995;330:613-622.

67. Chan PH. Role of oxidants in ischemic brain damage. Stroke 1996;27:1124-1129.

68. Saeed SA, Shad KF, Saleem T, Javed F, Khan MU. Some new prospects in the understanding of the molecular basis of the pathogenesis of stroke. Exp Brain Res 2007;182:1-10.

69. Gariballa SE, Hutchin TP, Sinclair AJ. Antioxidant capacity after acute ischaemic stroke. OJM 2002;95:685-690.

70. Spranger M, Krempien S, Schwab S, Donneberg S, Hacke W. Superoxide dismutase activity in serum of patients with acute cerebral ischemic injury. Correlation with clinical course and infarct size. Stroke 1997;28:2425-2428.

71. Alfieri A, Srivastava S, Siow RC, Modo M, Fraser PA, Mann GE. Targeting the Nrf2-Keap1 antioxidant defence pathway for neurovascular protection in stroke. J Physiol 2011;589:4125-4136.

72. Margaill I, Plotkine $M$, Lerouet D. Antioxidant strategies in the treatment of stroke. Free Radical Bio Med 2005;39:429443.

73. Zhang C, Shu L, Kong AN. MicroRNAs: new players in cancer prevention targeting Nrf2, oxidative stress and inflammatory pathways. Curr Pharmacol Rep 2015;1:21-30.

74. Johnson JA, Johnson DA, Kraft AD, Calkins MJ, Jakel RJ, Vargas MR, et al. The Nrf2-ARE pathway: an indicator and modulator of oxidative stress in neurodegeneration. Ann N Y Acad Sci 2008;1147:61-69.

75. Dang J, Brandenburg LO, Rosen C, Fragoulis A, Kipp M, Pufe $T$, et al. Nrf2 expression by neurons, astroglia, and microglia in the cerebral cortical penumbra of ischemic rats. $J \mathrm{Mol}$ Neurosci 2012;46:578-584.

76. Papp D, Lenti K, Módos D, Fazekas D, Dúl Z, Türei D, et al. The NRF2-related interactome and regulome contain multifunctional proteins and fine-tuned autoregulatory loops. FEBS Lett 2012;586:1795-1802.

77. Liu $P$, Zhao H, Wang R, Wang P, Tao Z, Gao L, et al. MicroRNA-424 protects against focal cerebral ischemia and reperfusion injury in mice by suppressing oxidative stress. Stroke 
2015;46:513-519.

78. Wang $P$, Liang $X, L u$ Y, Zhao $X$, Liang J. MicroRNA-93 downregulation ameliorates cerebral ischemic injury through the Nrf2/HO-1 defense pathway. Neurochem Res 2016;41:26272635.

79. Jiang S, Deng C, Lv J, Fan C, Hu W, Di S, et al. Nrf2 weaves an elaborate network of neuroprotection against stroke. $\mathrm{Mol}$ Neurobiol 2016;54:1440-1455.

80. Singh B, Bhat HK. Superoxide dismutase 3 is induced by antioxidants, inhibits oxidative DNA damage and is associated with inhibition of estrogen-induced breast cancer. Carcinogenesis 2012;33:2601-2610.

81. Stamova BS, Tian Y, Nordahl CW, Shen MD, Rogers S, Amaral $D G$, et al. Evidence for differential alternative splicing in blood of young boys with autism spectrum disorders. Mol Autism 2013;4:30.

82. Mravec B. The role of the vagus nerve in stroke. Auton Neurosci 2010;158:8-12.

83. Jiang $Y$, Li L, Tan $X$, Liu B, Zhang Y, Li C. miR-210 mediates vagus nerve stimulation-induced antioxidant stress and antiapoptosis reactions following cerebral ischemia/reperfusion injury in rats. J Neurochem 2015;134:173-181.

84. Li P, Shen M, Gao F, Wu J, Zhang J, Teng F, et al. An antagomir to microRNA-106b-5p ameliorates cerebral ischemia and reperfusion injury in rats via inhibiting apoptosis and oxidative stress. Mol Neurobiol 2016 Mar 29 [Epub]. http://dx.doi.org/10.1007/s12035-016-9842-1.

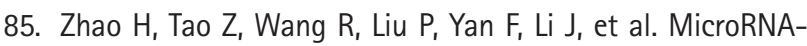
23a-3p attenuates oxidative stress injury in a mouse model of focal cerebral ischemia-reperfusion. Brain Res 2014;1592:65-72.

86. Tomimoto $H_{1}$ Akiguchi I, Wakita H, Lin JX, Budka H. Cyclooxygenase-2 is induced in microglia during chronic cerebral ischemia in humans. Acta Neuropathol 2000;99:26-30.

87. Strillacci A, Griffoni C, Sansone P, Paterini P, Piazzi G, Lazzarini $G$, et al. MiR-101 downregulation is involved in cyclooxygenase-2 overexpression in human colon cancer cells. Exp Cell Res 2009;315:1439-1447.

88. Iyer A, Zurolo E, Prabowo A, Fluiter K, Spliet WG, van Rijen $\mathrm{PC}$, et al. MicroRNA-146a: a key regulator of astrocyte-mediated inflammatory response. PLoS One 2012;7:e44789.

89. Moskowitz MA, Lo EH, ladecola C. The science of stroke: mechanisms in search of treatments. Neuron 2010;67:181198.

90. Chamorro A, Hallenbeck J. The harms and benefits of inflammatory and immune responses in vascular disease. Stroke 2006;37:291-293.

91. McColl B, Allan SM, Rothwell NJ. Systemic infection, inflam- mation and acute ischemic stroke. Neuroscience 2009;158:1049-1061.

92. Pan J, Palmateer J, Schallert T, Hart M, Pandya A, Vandenbark $A A$, et al. Novel humanized recombinant $T$ cell receptor ligands protect the female brain after experimental stroke. Trans/ Stroke Res 2014;5:577-585.

93. Amantea D, Nappi G, Bernardi G, Bagetta G, Corasaniti MT. Post-ischemic brain damage: pathophysiology and role of inflammatory mediators. FEBS J 2009;276:13-26.

94. Kriz J. Inflammation in ischemic brain injury: timing is important. Crit Rev Neurobiol 2006;18:145-157.

95. Stanimirovic DB, Wong J, Shapiro A, Durkin JP. Increase in surface expression of ICAM-1, VCAM-1 and e-selectin in human cerebromicrovascular endothelial cells subjected to ischemia-like insults. Acta Neurochir Supp/ 1997;70:12-16.

96. Becker K. Inflammation and acute stroke. Curr Opin Neurol 1998;11:45-49.

97. Hoehn BD, Palmer TD, Steinberg GK. Neurogenesis in rats after focal cerebral ischemia is enhanced by indomethacin. Stroke 2005;36:2718-2724.

98. Ekdahl CT, Claasen JH, Bonde S, Kokaia Z, Lindvall O. Inflammation is detrimental for neurogenesis in adult brain. Proc Natl Acad Sci U S A 2003;100:13632-13637.

99. Griffin WS, Sheng JG, Gentleman SM, Graham DI, Mrak RE, Roberts GW. Microglial interleukin-I alpha expression in human head injury: correlations with neuronal and neuritic beta-amyloid precursor protein expression. Neurosci Lett 1994;176:133-136.

100. Mrak RE, Griffin WS. Glia and their cytokines in progression of neurodegeneration. Neurobiol Aging 2005;26:349-354.

101. Eikelenboom $P$, Rozemuller AJ, Hoozemans JJ, Veerhuis $R_{1}$ van Gool WA. Neuroinflammation and Alzheimer disease: clinical and therapeutic implications. Alzheimer Dis Assoc Dis 2000;14 Suppl 1:S54-S61.

102. Jin R, Yang G, Li G. Inflammatory mechanisms in ischemic stroke: role of inflammatory cells. J Leukoc Biol 2010;87:779789.

103. Morganti-Kossman M, Lenzlinger PM, Hans V, Stahel P, Csu-

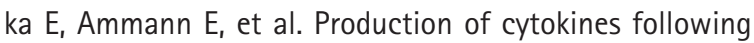
brain injury: beneficial and deleterious for the damaged tissue. Mol Psychiatry 1997;2:133-136.

104. Luna JM, Moon YP, Liu KM, Spitalnik S, Paik MC, Cheung K, et al. High-sensitivity $\mathrm{C}$-reactive protein and interleukin-6-dominant inflammation and ischemic stroke risk: the Northern Manhattan study. Stroke 2014;45:979-987.

105. Lucas SM, Rothwell NJ, Gibson RM. The role of inflammation in CNS injury and disease. Br J Pharmacol 2006;147 Suppl $1: S 232-S 240$. 
106. Pena-Philippides JC, Yang Y, Bragina O, Hagberg S, Nemoto $E_{1}$ Roitbak T. Effect of pulsed electromagnetic field (PEMF) on infarct size and inflammation after cerebral ischemia in mice. Trans/ Stroke Res 2014;5:491-500.

107. Yilmaz G, Granger DN. Cell adhesion molecules and ischemic stroke. Neurol Res 2008;30:783-793.

108. Ferrarese $C$, Mascarucci $P$, Zoia C, Cavarretta R, Frigo $M$, Begni $B$, et al. Increased cytokine release from peripheral blood cells after acute stroke. J Cereb Blood Flow Metab 1999;19:1004-1009.

109. Han HS, Yenari MA. Cellular targets of brain inflammation in stroke. Curr Opin Investig Drugs 2003;4:522-529.

110. Baeuerle PA, Henkel T. Function and activation of NF-kappa $b$ in the immune system. Annu Rev Immunol 1994;12:141-179.

111. Zhang R, Chopp M, Zhang Z, Jiang N, Powers $C$. The expression of $\mathrm{P}$ - and $\mathrm{E}$-selectins in three models of middle cerebral artery occlusion. Brain Res 1998;785:207-214.

112. Danton $\mathrm{GH}$, Dietrich WD. Inflammatory mechanisms after ischemia and stroke. J Neuropath Exp Neurol 2003;62:127136.

113. Jin R, Yang G, Li G. Molecular insights and therapeutic targets for blood-brain barrier disruption in ischemic stroke: critical role of matrix metalloproteinases and tissue-type plasminogen activator. Neurobiol Dis 2010;38:376-385.

114. Saugstad JA. MicroRNAs as effectors of brain function with roles in ischemia and injury, neuroprotection, and neurodegeneration. J Cereb Blood Flow Metab 2010;30:1564-1576.

115. Tan JR, Koo $Y X$, Kaur $P$, Liu F, Armugam $A$, Wong $P H$, et al. microRNAs in stroke pathogenesis. Curr Mol Med 2011;11:7692.

116. Zhao H, Wang J, Gao L, Wang R, Liu X, Gao Z, et al. MiRNA-424 protects against permanent focal cerebral ischemia injury in mice involving suppressing microglia activation. Stroke 2013;44:1706-1713.

117. Ni J, Wang $X$, Chen $S$, Liu $H$, Wang $Y, X u$, et al. MicroRNA let-7c-5p protects against cerebral ischemia injury via mechanisms involving the inhibition of microglia activation. Brain Behav Immun 2015;49:75-85.

118. Ponomarev ED, Veremeyko T, Barteneva N, Krichevsky AM, Weiner HL. MicroRNA-124 promotes microglia quiescence and suppresses EAE by deactivating macrophages via the $\mathrm{C} /$ EBP- $\alpha$-PU.1 pathway. Nat Med 2011;17:64-70.

119. Weinstein JR, Koerner IP, Möller T. Microglia in ischemic brain injury. Future Neurol 2010;5:227-246.

120. Kawai T, Akira S. The role of pattern-recognition receptors in innate immunity: update on Toll-like receptors. Nat Immun 2010;11:373-384.

121. Karikó K, Ni H, Capodici J, Lamphier M, Weissman D. mRNA is an endogenous ligand for Toll-like receptor 3. J Biol Chem 2004;279:12542-12550.

122. Akira S. TLR signaling. In: From Innate Immunity to Immunological Memory. Berlin, Heideleberg: Springer, 2006;1-16.

123. Brea D, Blanco M, Ramos-Cabrer P, Moldes O, Arias S, Pérez-Mato $M$, et al. Toll-like receptors 2 and 4 in ischemic stroke: outcome and therapeutic values. J Cereb Blood Flow Metab 2011;31:1424-1431.

124. Caso JR, Pradillo JM, Hurtado O, Lorenzo P, Moro MA, Lizasoain I. Toll-like receptor 4 is involved in brain damage and inflammation after experimental stroke. Circulation 2007;115:1599-1608

125. Yao L, Kan EM, Lu J, Hao A, Dheen ST, Kaur C, et al. Toll-like receptor 4 mediates microglial activation and production of inflammatory mediators in neonatal rat brain following hypoxia: role of TLR4 in hypoxic microglia. J Neuroinflammation 2013;10:23

126. Zhang L, Li YJ, Wu XY, Hong Z, Wei WS. MicroRNA-181c negatively regulates the inflammatory response in oxygen-glucose-deprived microglia by targeting Toll-like receptor 4. J Neurochem 2015;132:713-723.

127. Wen Y, Zhang X, Dong L, Zhao J, Zhang C, Zhu C. Acetylbritannilactone modulates microRNA-155-mediated inflammatory response in ischemic cerebral tissues. Mol Med 2015;21:197-209.

128. Cardoso AL, Guedes JR, Pereira de Almeida L, Pedroso de Lima MC. miR-155 modulates microglia-mediated immune response by down-regulating SOCS-1 and promoting cytokine and nitric oxide production. Immunology 2012;135:7388.

129. Bala $S$, Marcos $M$, Kodys $K$, Csak T, Catalano $D$, Mandrekar $P$, et al. Up-regulation of microRNA-155 in macrophages contributes to increased tumor necrosis factor $\alpha$ (TNF $\alpha$ ) production via increased mRNA half-life in alcoholic liver disease. $J$ Biol Chem 2011;286:1436-1444.

130. Wang $P$, Hou J, Lin L, Wang C, Liu X, Li D, et al. Inducible microRNA-155 feedback promotes type I IFN signaling in antiviral innate immunity by targeting suppressor of cytokine signaling 1. J Immunol 2010;185:6226-6233.

131. Zhang L, Dong LY, Li YJ, Hong Z, Wei WS. The microRNA miR181c controls microglia-mediated neuronal apoptosis by suppressing tumor necrosis factor. J Neuroinflammation 2012;9:211.

132. Banerjee $S$, Xie N, Cui $H$, Tan Z, Yang $S$, Icyuz M, et al. MicroRNA let-7c regulates macrophage polarization. J Immunol 2013;190:6542-6549.

133. Xie W, Li M, Xu N, Lv Q, Huang N, He J, et al. Mir-181a regulates inflammation responses in monocytes and macro- 
phages. PLoS One 2013;8:e58639.

134. Sharma A, Kumar M, Aich J, Hariharan M, Brahmachari SK, Agrawal $A$, et al. Posttranscriptional regulation of interleukin-10 expression by hsa-miR-106a. Proc Natl Acad Sci U S A 2009;106:5761-5766.

135. Ponomarev ED, Veremeyko T, Weiner HL. MicroRNAs are universal regulators of differentiation, activation, and polarization of microglia and macrophages in normal and diseased CNS. Glia 2013;61:91-103.

136. Liu Y, Zhang J, Han R, Liu H, Sun D, Liu X. Downregulation of serum brain specific microRNA is associated with inflammation and infarct volume in acute ischemic stroke. J Clin Neurosci 2015;22:291-295.

137. Yan W, Zhang W, Sun L, Liu Y, You G, Wang Y, et al. Identification of MMP-9 specific microRNA expression profile as potential targets of anti-invasion therapy in glioblastoma multiforme. Brain Res 2011;1411:108-115.

138. Jones S, Watkins G, Le Good N, Roberts S, Murphy CL, Brockbank $\mathrm{SM}$, et al. The identification of differentially expressed microRNA in osteoarthritic tissue that modulate the production of TNF- $\alpha$ and MMP13. Osteoarthritis Cartilage 2009;17:464-472.

139. Bazzoni F, Rossato M, Fabbri M, Gaudiosi D, Mirolo M, Mori $L$, et al. Induction and regulatory function of miR-9 in human monocytes and neutrophils exposed to proinflammatory signals. Proc Natl Acad Sci USA 2009;106:5282-5287.

140. Vandenabeele P, Galluzzi L, Berghe TV, Kroemer G. Molecular mechanisms of necroptosis: an ordered cellular explosion. Nat Rev Mol Cell Biol 2010;11:700-714.

141. Wei L, Ying DJ, Cui L, Langsdorf J, Yu SP. Necrosis, apoptosis and hybrid death in the cortex and thalamus after barrel cortex ischemia in rats. Brain Res 2004;1022:54-61.

142. Ünal-Çevik I, Kılınç M, Can A, Gürsoy-Özdemir Y, Dalkara T. Apoptotic and necrotic death mechanisms are concomitantly activated in the same cell after cerebral ischemia. Stroke 2004;35:2189-2194.

143. Adams JM. Ways of dying: multiple pathways to apoptosis. Genes Dev 2003;17:2481-2495.

144. Kroemer G, Galluzzi L, Brenner C. Mitochondrial membrane permeabilization in cell death. Physiol Rev 2007;87:99-163.

145. Jin K, Graham SH, Mao X, Nagayama T, Simon RP, Greenberg DA. Fas (cd95) may mediate delayed cell death in hippocampal CA1 sector after global cerebral ischemia. J Cereb Blood Flow Metab 2001;21:1411-1421.

146. Green DR. Apoptotic pathways: ten minutes to dead. Cell 2005;121:671-674.

147. Nikoletopoulou V, Markaki M, Palikaras K, Tavernarakis N. Crosstalk between apoptosis, necrosis and autophagy. Bio- chim Biophys Acta 2013;1833:3448-3459.

148. Culmsee C, Zhu C, Landshamer S, Becattini B, Wagner E, Pellecchia $\mathrm{M}$, et al. Apoptosis-inducing factor triggered by poly (ADP-ribose) polymerase and Bid mediates neuronal cell death after oxygen-glucose deprivation and focal cerebral ischemia. J Neurosci 2005;25:10262-10272.

149. Broughton BR, Reutens DC, Sobey CG. Apoptotic mechanisms after cerebral ischemia. Stroke 2009;40:e331-e339.

150. Li H, Colbourne F, Sun P, Zhao Z, Buchan AM, ladecola C. Caspase inhibitors reduce neuronal injury after focal but not global cerebral ischemia in rats. Stroke 2000;31:176-182.

151. Peng Z, Li J, Li Y, Yang X, Feng S, Han S, et al. Downregulation of miR-181b in mouse brain following ischemic stroke induces neuroprotection against ischemic injury through targeting heat shock protein A5 and ubiquitin carboxyl-terminal hydrolase isozyme L1. J Neurosci Res 2013;91:13491362.

152. Yin KJ, Deng Z, Huang $H$, Hamblin M, Xie C, Zhang J, et al. miR-497 regulates neuronal death in mouse brain after transient focal cerebral ischemia. Neurobiol Dis 2010;38:1726.

153. Zhang JF, Shi LL, Zhang L, Zhao ZH, Liang F, Xu X, et al. MicroRNA-25 negatively regulates cerebral ischemia/reperfusion injury-induced cell apoptosis through Fas/FasL pathway. J Mol Neurosci 2016;58:507-516.

154. Schickel R, Park SM, Murmann AE, Peter ME. miR-200c regulates induction of apoptosis through CD95 by targeting FAP1. Mol Cell 2010;38:908-915.

155. Buller B, Liu $X$, Wang $X$, Zhang RL, Zhang L, Hozeska-Solgot $A$, et al. MicroRNA-21 protects neurons from ischemic death. FEBS J 2010;277:4299-4307.

156. Seko Y, Kayagaki N, Seino K, Yagita H, Okumura K, Nagai R. Role of Fas/FasL pathway in the activation of infiltrating cells in murine acute myocarditis caused by Coxsackievirus B3. J Am Coll Cardiol 2002;39:1399-1403.

157. Liu Y, Pan Q, Zhao Y, He C, Bi K, Chen Y, et al. MicroRNA-155 regulates ROS production, no generation, apoptosis and multiple functions of human brain microvessel endothelial cells under physiological and pathological conditions. J Cell Biochem 2015;116:2870-2881.

158. Tao Z, Zhao H, Wang R, Liu P, Yan F, Zhang C, et al. Neuroprotective effect of microRNA-99a against focal cerebral ischemia-reperfusion injury in mice. J Neurol Sci 2015;355:113-119.

159. Wei N, Xiao L, Xue R, Zhang D, Zhou J, Ren H, et al. MicroRNA-9 mediates the cell apoptosis by targeting $\mathrm{Bcl} 2 \mathrm{l} 11$ in ischemic stroke. Mol Neurobiol 2015;53:6809-6817.

160. Luo S, Rubinsztein DC. BCL2/11/BIM: a novel molecular link 
between autophagy and apoptosis. Autophagy 2013;9:104105.

161. Sionov RV, Vlahopoulos SA, Granot Z. Regulation of BIM in health and disease. Oncotarget 2015;6:23058-23134.

162. Wiessner C, Allegrini PR, Rupalla K, Sauer D, Oltersdorf T, McGregor $A L$, et al. Neuron-specific transgene expression of $\mathrm{Bcl}-\mathrm{XL}$ but not $\mathrm{Bcl}-2$ genes reduced lesion size after permanent middle cerebral artery occlusion in mice. Neurosci Lett 1999;268:119-122.

163. Moon JM, Xu L, Giffard RG. Inhibition of microRNA-181 reduces forebrain ischemia-induced neuronal loss. J Cereb Blood Flow Metab 2013;33:1976-1982.

164. Zhai F, Zhang X, Guan Y, Yang X, Li Y, Song G, et al. Expression profiles of microRNAs after focal cerebral ischemia/reperfusion injury in rats. Neural Regen Res 2012;7:917-923.

165. Huang W, Liu X, Cao J, Meng F, Li M, Chen B, et al. Mir-134 regulates ischemia/reperfusion injury-induced neuronal cell death by regulating CREB signaling. J Mol Neurosci 2015;55:821-829.

166. Chi $W$, Meng $F$, Li $Y$, Li $P$, Wang $G$, Cheng $H$, et al. Impact of microRNA-134 on neural cell survival against ischemic injury in primary cultured neuronal cells and mouse brain with ischemic stroke by targeting HSPA12B. Brain Res 2014;1592:22-33.

167. Kang L, Zhang G, Yan $Y, K e ~ K, W u X, G a o ~ Y$, et al. The role of HSPA12B in regulating neuronal apoptosis. Neurochem Res 2013;38:311-320.

168. Ma Y, Lu C, Li C, Li R, Zhang Y, Ma H, et al. Overexpression of HSPA12B protects against cerebral ischemia/reperfusion injury via a PI3K/Akt-dependent mechanism. Biochim Biophys Acta 2013;1832:57-66.

169. Lim KY, Chua JH, Tan JR, Swaminathan P, Sepramaniam $S$, Armugam $A$, et al. MicroRNAs in cerebral ischemia. Transl Stroke Res 2010;1:287-303.

170. Liu $X$, Li F, Zhao S, Luo Y, Kang J, Zhao H, et al. MicroRNA124-mediated regulation of inhibitory member of apoptosisstimulating protein of p53 family in experimental stroke. Stroke 2013;44:1973-1980.

171. Sullivan A, Lu X. ASPP: a new family of oncogenes and tumour suppressor genes. Br J Cancer 2007;96:196-200.

172. Yang L, Xiong Y, Hu XF, Du YH. MicroRNA-323 regulates ischemia/reperfusion injury-induced neuronal cell death by targeting BRI3. Int J Clin Exp Path 2015;8:10725-10733.

173. Seto SW, Chang D, Jenkins A, Bensoussan A, Kiat H. Angiogenesis in ischemic stroke and angiogenic effects of Chinese herbal medicine. J Clin Med 2016;5:56.

174. Fonarow GC, Zhao X, Smith EE, Saver JL, Reeves MJ, Bhatt $\mathrm{DL}$, et al. Door-to-needle times for tissue plasminogen acti- vator administration and clinical outcomes in acute ischemic stroke before and after a quality improvement initiative. JAMA 2014;311:1632-1640.

175. Del Zoppo GJ, Saver JL, Jauch EC, Adams HP; American Heart Association Stroke Council. Expansion of the time window for treatment of acute ischemic stroke with intravenous tissue plasminogen activator: a science advisory from the American Heart Association/American Stroke Association. Stroke 2009;40:2945-2948.

176. IST-3 collaborative group, Sandercock P, Wardlaw JM, Lindley RI, Dennis M, Cohen $\mathrm{G}$, et al. The benefits and harms of intravenous thrombolysis with recombinant tissue plasminogen activator within $6 \mathrm{~h}$ of acute ischaemic stroke (the third international stroke trial [IST-3]): a randomised controlled trial. Lancet 2012;379:2352-2363.

177. Kaur J, Zhao Z, Klein GM, Lo EH, Buchan AM. The neurotoxicity of tissue plasminogen activator? J Cereb Blood Flow Metab 2004;24:945-963.

178. Fan $M, X u H$, Wang $L$, Luo $H$, Zhu $X$, Cai $P$, et al. Tissue plasminogen activator neurotoxicity is neutralized by recombinant ADAMTS 13. Sci Rep 2016;6:25971.

179. Armstead WM, Nassar T, Akkawi S, Smith DH, Chen XH, Cines $D B$, et al. Neutralizing the neurotoxic effects of exogenous and endogenous tPA. Nat Neurosci 2006;9:1150-1155.

180. Yepes M, Sandkvist M, Wong MK, Coleman TA, Smith $E_{1}$ Cohan $\mathrm{SL}$, et al. Neuroserpin reduces cerebral infarct volume and protects neurons from ischemia-induced apoptosis. Blood 2000;96:569-576.

181. Shi ZS, Loh Y, Walker G, Duckwiler GR; MERCl and Multi$\mathrm{MERCI}$ Investigators. Clinical outcomes in middle cerebral artery trunk occlusions versus secondary division occlusions after mechanical thrombectomy: pooled analysis of the mechanical embolus removal in cerebral ischemia (MERCI) and multi MERCl trials. Stroke 2010;41:953-960.

182. Onwuekwe I, Ezeala-Adikaibe B. Ischemic stroke and neuroprotection. Ann Med Health Sci Res 2012;2:186-190.

183. Guyot L, Diaz FG, O'regan MH, McLeod S, Park H, Phillis JW. Real-time measurement of glutamate release from the ischemic penumbra of the rat cerebral cortex using a focal middle cerebral artery occlusion model. Neurosci Lett 2001;299:37-40.

184. Ohta K, Graf R, Rosner G, Heiss WD. Calcium ion transients in peri-infarct depolarizations may deteriorate ion homeostasis and expand infarction in focal cerebral ischemia in cats. Stroke 2001;32:535-543.

185. Annunziato L, Pignataro G, Di Renzo GF. Pharmacology of brain $\mathrm{Na}^{+} / \mathrm{Ca}^{2+}$ exchanger: from molecular biology to therapeutic perspectives. Pharmacol Rev2004;56:633-654. 
186. Boscia F, Gala R, Pignataro G, De Bartolomeis $A$, Cicale $M_{1}$

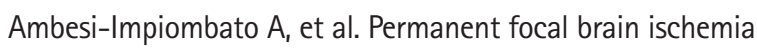
induces isoform-dependent changes in the pattern of $\mathrm{Na}^{+} /$ $\mathrm{Ca}^{2+}$ exchanger gene expression in the ischemic core, periinfarct area, and intact brain regions. J Cereb Blood Flow Metab 2006;26:502-517.

187. Tortiglione A, Pignataro G, Minale M, Secondo A, Scorziello $A$, Di Renzo GF, et al. $\mathrm{Na}^{+} /$exchanger in $\mathrm{Na}^{+}$efflux- $\mathrm{Ca}^{2+}$ influx mode of operation exerts a neuroprotective role in cellular models of in vitro anoxia and in vivo cerebral ischemia. Ann NYAcad Sci 2002;976:408-412.

188. Molinaro P, Cantile M, Cuomo O, Secondo A, Pannaccione $A$, Ambrosino $P$, et al. Neurounina-1, a novel compound that increases $\mathrm{Na}^{+} / \mathrm{Ca}^{2+}$ exchanger activity, effectively protects against stroke damage. Mol Pharmacol 2013;83:142-156.

189. Vinciguerra A, Formisano L, Cerullo $P$, Guida N, Cuomo O, Esposito $A$, et al. MicroRNA-103-1 selectively downregulates brain NCX1 and its inhibition by anti-miRNA ameliorates stroke damage and neurological deficits. Mol Ther 2014;22:1829-1838.

190. Xu ப, Ouyang YB, Xiong X, Stary CM, Giffard RG. Post-stroke treatment with miR-181 antagomir reduces injury and improves long-term behavioral recovery in mice after focal cerebral ischemia. Exp Neurol 2015;264:1-7.

191. Taylor A, Verhagen J, Blaser K, Akdis M, Akdis CA. Mechanisms of immune suppression by interleukin-10 and transforming growth factor- $\beta$ : the role of T regulatory cells. Immunology 2006;117:433-442.

192. Iadecola C, Anrather J. The immunology of stroke: from mechanisms to translation. Nat Med 2011;17:796-808.

193. Buisson A, Nicole O, Docagne $F$, Sartelet $H$, Mackenzie ET, Vivien D. Up-regulation of a serine protease inhibitor in astrocytes mediates the neuroprotective activity of transforming growth factor $\beta 1$. FASEB J 1998;12:1683-1691.

194. Grilli M, Barbieri I, Basudev $H$, Brusa R, Casati C, Lozza G, et al. Interleukin-10 modulates neuronal threshold of vulnerability to ischaemic damage. Eur J Neurosci 2000;12:22652272.

195. ladecola C, Anrather J. Stroke research at a crossroad: asking the brain for directions. Nat Neurosci 2011;14:1363-1368.

196. Cheng Y, Sun AY. Oxidative mechanisms involved in kainate-induced cytotoxicity in cortical neurons. Neurochem Res 1994;19:1557-1564.

197. Lapchak PA, Chapman DF, Zivin JA. Pharmacological effects of the spin trap agents $\mathrm{N}$-t-butyl-phenylnitrone (PBN) and 2,2,6, 6-tetramethylpiperidine-N-oxyl (TEMPO) in a rabbit thromboembolic stroke model: combination studies with the thrombolytic tissue plasminogen activator. Stroke
2001;32:147-153.

198. Johnson JA, Johnson DA, Kraft AD, Calkins MJ, Jakel RJ, Vargas MR, et al. The Nrf2-ARE pathway: an indicator and modulator of oxidative stress in neurodegeneration. Ann NY Acad Sci 2008;1147:61-69.

199. Jessell T, Sanes J. The generation and survival of nerve cells. In: Kandel E, Schwartz JH. Principles of Neural Sciences. New York: McGraw-Hill, 2000;1041-1062.

200. Cheng YD, Al-Khoury L, Zivin JA. Neuroprotection for ischemic stroke: two decades of success and failure. NeuroRx 2004;1:36-45.

201. Ekdahl CT, Kokaia Z, Lindvall O. Brain inflammation and adult neurogenesis: the dual role of microglia. Neuroscience 2009;158:1021-1029.

202. Selvamani A, Sathyan P, Miranda RC, Sohrabji F. An antagomir to microRNA Let7f promotes neuroprotection in an ischemic stroke model. PLoS One 2012;7:e32662.

203. Mellios N, Huang HS, Grigorenko A, Rogaev E, Akbarian S. A set of differentially expressed miRNAs, including miR-30a$5 p$, act as post-transcriptional inhibitors of BDNF in prefrontal cortex. Hum Mol Genet 2008;17:3030-3042.

204. Zeng L, He X, Wang Y, Tang Y, Zheng $C$, Cai H, et al. MicroRNA-210 overexpression induces angiogenesis and neurogenesis in the normal adult mouse brain. Gene Ther 2014;21:3743.

205. Wang YQ, Cui HR, Yang SZ, Sun HP, Qiu MH, Feng XY, et al. VEGF enhance cortical newborn neurons and their neurite development in adult rat brain after cerebral ischemia. Neurochem Int 2009;55:629-636.

206. Zhang R, Zhang Z, Wang L, Wang Y, Gousev A, Zhang L, et al. Activated neural stem cells contribute to stroke-induced neurogenesis and neuroblast migration toward the infarct boundary in adult rats. J Cereb Blood Flow Metab 2004;24:441-448.

207. Shruster A, Ben-Zur T, Melamed E, Offen D. Wht signaling enhances neurogenesis and improves neurological function after focal ischemic injury. PLoS One 2012;7:e40843.

208. Bambakidis NC, Petrullis M, Kui X, Rothstein B, Karampelas I, Kuang $Y$, et al. Improvement of neurological recovery and stimulation of neural progenitor cell proliferation by intrathecal administration of Sonic hedgehog. J Neurosurg 2012;116:1114-1120.

209. Sims JR, Lee SW, Topalkara K, Qiu J, Xu J, Zhou Z, et al. Sonic hedgehog regulates ischemia/hypoxia-induced neural progenitor proliferation. Stroke 2009;40:3618-3626.

210. Androutsellis-Theotokis A, Leker RR, Soldner F, Hoeppner DJ, Ravin $R$, Poser SW, et al. Notch signalling regulates stem cell numbers in vitro and in vivo. Nature 2006;442:823-826. 
211. Pang $L$, Ye W, Che XM, Roessler BJ, Betz AL, Yang GY. Reduction of inflammatory response in the mouse brain with adenoviral-mediated transforming growth factor- $\beta 1$ expression. Stroke 2001;32:544-552.

212. Liu FJ, Lim KY, Kaur P, Sepramaniam S, Armugam A, Wong PT, et al. MicroRNAs involved in regulating spontaneous recovery in embolic stroke model. PLoS One 2013;8:e66393.

213. Cheng LC, Pastrana E, Tavazoie M, Doetsch F. miR-124 regulates adult neurogenesis in the subventricular zone stem cell niche. Nat Neurosci 2009;12:399-408.

214. Liu XS, Chopp M, Zhang RL, Tao T, Wang XL, Kassis $H$, et al. MicroRNA profiling in subventricular zone after stroke: MiR124a regulates proliferation of neural progenitor cells through Notch signaling pathway. PLoS One 2011;6:e23461.

215. Delaloy C, Liu L, Lee JA, Su H, Shen F, Yang GY, et al. MicroRNA-9 coordinates proliferation and migration of human embryonic stem cell-derived neural progenitors. Cell Stem Cell 2010;6:323-335.

216. Arenillas JF, Sobrino T, Castillo J, Dávalos A. The role of angiogenesis in damage and recovery from ischemic stroke. Curr Treat Options Cardiovasc Med 2007;9:205-212.

217. Wu F, Yang Z, Li G. Role of specific microRNAs for endothelial function and angiogenesis. Biochem Biophys Res Commun 2009;386:549-553.

218. Zeng L, Liu J, Wang Y, Wang L, Weng S, Tang Y, et al. MicroRNA-210 as a novel blood biomarker in acute cerebral ischemia. Front Biosci (Elite Ed) 2011;3:1265-1272.

219. Fasanaro $P$, Greco $S$, Ivan $M$, Capogrossi MC, Martelli F. microRNA: emerging therapeutic targets in acute ischemic diseases. Pharmacol Ther 2010;125:92-104.

220. Kulshreshtha $R$, Ferracin $M$, Wojcik SE, Garzon $R$, Alder $H_{\text {, }}$ Agosto-Perez FJ, et al. A microRNA signature of hypoxia. Mol Cell Biol 2007;27:1859-1867.

221. Crosby ME, Devlin CM, Glazer PM, Calin GA, Ivan M. Emerging roles of microRNAs in the molecular responses to hypoxia. Curr Pharm Des 2009;15:3861-3866.

222. Bonauer $A$, Carmona $G$, Iwasaki $M$, Mione $M$, Koyanagi $M$, Fischer $A$, et al. MicroRNA-92a controls angiogenesis and functional recovery of ischemic tissues in mice. Science 2009;324:1710-1713.

223. Sun $Y$, Jin $K$, Xie $L$, Childs J, Mao XO, Logvinova $A$, et al. VEGF-induced neuroprotection, neurogenesis, and angiogenesis after focal cerebral ischemia. J Clin Invest 2003;111:18431851

224. Shen F, Fan Y, Su H, Zhu Y, Chen Y, Liu W, et al. Adeno-associated viral vector-mediated hypoxia-regulated VEGF gene transfer promotes angiogenesis following focal cerebral ischemia in mice. Gene Ther 2008;15:30-39.
225. Li Y, Mao L, Gao Y, Baral S, Zhou Y, Hu B. MicroRNA-107 contributes to post-stroke angiogenesis by targeting Dicer-1. Sci Rep 2015;5:13316.

226. Chen $Z$, Lai TC, Jan YH, Lin FM, Wang WC, Xiao H, et al. Hypoxia-responsive miRNAs target argonaute 1 to promote angiogenesis. J Clin Invest 2013;123:1057-1067.

227. Yin KJ, Olsen K, Hamblin M, Zhang J, Schwendeman SP, Chen YE. Vascular endothelial cell-specific microRNA-15a inhibits angiogenesis in hindlimb ischemia. J Biol Chem 2012;287:2705527064.

228. Yin KJ, Hamblin M, Chen YE. Angiogenesis-regulating microRNAs and ischemic stroke. Curr Vasc Pharmacol 2015;13:352365.

229. Hua Z, Lv Q, Ye W, Wong CK, Cai G, Gu D, et al. Mirna-directed regulation of VEGF and other angiogenic factors under hypoxia. PLoS One 2006; 1:e116.

230. Chen $Y$, Leal $A D$, Patel $S$, Gorski $D H$. The homeobox gene GAX activates p21WAF1/CIP1 expression in vascular endothelial cells through direct interaction with upstream AT-rich sequences. J Biol Chem 2007;282:507-517.

231. Patel $S$, Leal $A D$, Gorski DH. The homeobox gene Gax inhibits angiogenesis through inhibition of nuclear factor-кb-dependent endothelial cell gene expression. Cancer Res 2005;65:14141424.

232. Chen Y, Gorski DH. Regulation of angiogenesis through a microRNA (miR-130a) that down-regulates antiangiogenic homeobox genes GAX and HOXA5. Blood 2008;111:1217-1226.

233. Bak M, Silahtaroglu A, Møller M, Christensen $M$, Rath MF, Skryabin $B$, et al. MicroRNA expression in the adult mouse central nervous system. RNA 2008;14:432-444.

234. Felli $N$, Fontana $L$, Pelosi $E$, Botta $R$, Bonci $D$, Facchiano $F$, et al. MicroRNAs 221 and 222 inhibit normal erythropoiesis and erythroleukemic cell growth via kit receptor down-modulation. Proc Natl Acad Sci USA 2005;102:18081-18086.

235. Suárez $Y$, Fernández-Hernando $C$, Pober JS, Sessa WC. Dicer dependent microRNAs regulate gene expression and functions in human endothelial cells. Circ Res 2007;100:11641173.

236. Li Z, Rana TM. Therapeutic targeting of microRNAs: current status and future challenges. Nat Rev Drug Discov 2014;13:622638.

237. Zhang $Y$, Wang Z, Gemeinhart RA. Progress in microRNA delivery. J Control Release 2013;172:962-974.

238. Li Y, Liu Y, Wang Z, Hou H, Lin Y, Jiang Y. MicroRNA: not far from clinical application in ischemic stroke. ISRN Stroke 2013;2013:1-7.

239. Zhang $H$, Shykind B, Sun T. Approaches to manipulating microRNAs in neurogenesis. Front Neurosci 2013;6:196. 
240. Krützfeldt J, Rajewsky N, Braich R, Rajeev KG, Tuschl T, Manoharan $M$, et al. Silencing of microRNAs in vivo with 'antagomirs'. Nature 2005;438:685-689.

241. Morrisey EE. The magic and mystery of miR-21. J Clin Invest 2010;120:3817-3819.

242. Patrick DM, Montgomery RL, Qi X, Obad S, Kauppinen S, Hill $J A$, et al. Stress-dependent cardiac remodeling occurs in the absence of microRNA-21 in mice. J Clin Invest 2010;120:39123916.

243. Jiang Y, Wei N, Lu T, Zhu J, Xu G, Liu X. Intranasal brain-derived neurotrophic factor protects brain from ischemic insult via modulating local inflammation in rats. Neuroscience 2011;172:398-405.

244. Jiang Y, Zhu J, Xu G, Liu X. Intranasal delivery of stem cells to the brain. Expert Opin Drug Deliv 2011;8:623-632.

245. Liu X. Clinical trials of intranasal delivery for treating neurological disorders--a critical review. Expert Opin Drug Deliv 2011;8:1681-1690.

246. Lee ST, Chu K, Jung KH, Kim JH, Huh JY, Yoon H, et al. Mir206 regulates brain-derived neurotrophic factor in Alzheimer disease model. Ann Neurol 2012;72:269-277.

247. Lewis DL, Hagstrom JE, Loomis AG, Wolff JA, Herweijer H. Efficient delivery of siRNA for inhibition of gene expression in postnatal mice. Nat Genet 2002;32:107-108.

248. Kishida T, Asada H, Gojo S, Ohashi S, Shin-Ya M, Yasutomi K, et al. Sequence-specific gene silencing in murine muscle induced by electroporation-mediated transfer of short interfering RNA. J Gene Med 2004;6:105-110.

249. Jickling GC, Ander BP, Zhan X, Noblett D, Stamova B, Liu D. MicroRNA expression in peripheral blood cells following acute ischemic stroke and their predicted gene targets. PLoS One 2014;9:e99283.

250. Laterza OF, Lim L, Garrett-Engele PW, Vlasakova K, Muniappa $\mathrm{N}$, Tanaka WK, et al. Plasma microRNAs as sensitive and specific biomarkers of tissue injury. Clin Chem 2009;55:19771983.

251. Weng H, Shen C, Hirokawa G, Ji X, Takahashi R, Shimada K, et al. Plasma mir-124 as a biomarker for cerebral infarction. Biomed Res 2011;32:135-141.

252. Long G, Wang F, Li H, Yin Z, Sandip C, Lou Y, et al. Circulating miR-30a, miR-126 and let-7b as biomarker for ischemic stroke in humans. BMC Neurol 2013;13:178.

253. epramaniam S, Tan JR, Tan KS, DeSilva DA, Tavintharan S, Woon FP, et al. Circulating microRNAs as biomarkers of acute stroke. Int J Mol Sci 2014;15:1418-1432.

254. Wang W, Sun G, Zhang L, Shi L, Zeng Y. Circulating microRNAs as novel potential biomarkers for early diagnosis of acute stroke in humans. J Stroke Cerebrovasc Dis 2014;23:2607-2613. 